\title{
Recognition of ATT Triplex and DNA:RNA Hybrid Structures by Benzothiazole Ligands
}

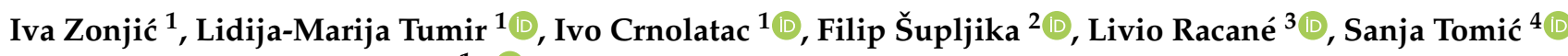 \\ and Marijana Radić Stojković ${ }^{1, *(1)}$
}

1 Laboratory for Biomolecular Interactions and Spectroscopy, Division of Organic Chemistry and Biochemistry, Ruđer Bošković Institute, Bijenička cesta 54, 10000 Zagreb, Croatia; iva.zonjic@irb.hr (I.Z.); tumir@irb.hr (L.-M.T.); icrnolat@irb.hr (I.C.)

2 Faculty of Food Technology and Biotechnology, University of Zagreb, Pierottijeva 6, 10000 Zagreb, Croatia; fsupljika@pbf.hr

3 Department of Applied Chemistry, Faculty of Textile Technology, University of Zagreb, Prilaz Baruna Filipovića 28a, 10000 Zagreb, Croatia; lracane@ttf.hr

4 Laboratory for Protein Biochemistry and Molecular Modelling, Division of Organic Chemistry and Biochemistry, Ruđer Bošković Institute, Bijenička cesta 54, 10000 Zagreb, Croatia; Sanja.Tomic@irb.hr

* Correspondence: mradic@irb.hr; Tel.: +38-51-4571220

Citation: Zonjić, I.; Tumir, L.-M.; Crnolatac, I.; Šuplijika, F.; Racané, L.; Tomić, S.; Radić Stojković, M. Recognition of ATT Triplex and DNA:RNA Hybrid Structures by Benzothiazole Ligands. Biomolecules 2022, 12, 374. https://doi.org/ $10.3390 /$ biom 12030374

Academic Editor: Francisco J. Blanco

Received: 31 January 2022

Accepted: 22 February 2022

Published: 27 February 2022

Publisher's Note: MDPI stays neutral with regard to jurisdictional claims in published maps and institutional affiliations.

Copyright: (C) 2022 by the authors. Licensee MDPI, Basel, Switzerland. This article is an open access article distributed under the terms and conditions of the Creative Commons Attribution (CC BY) license (https:// creativecommons.org/licenses/by/ $4.0 /)$.

\begin{abstract}
Interactions of an array of nucleic acid structures with a small series of benzothiazole ligands (bis-benzothiazolyl-pyridines-group 1, 2-thienyl/2-benzothienyl-substituted 6-(2-imidazolinyl) benzothiazoles-group 2, and three 2-aryl/heteroaryl-substituted 6-(2-imidazolinyl)benzothiazolesgroup 3) were screened by competition dialysis. Due to the involvement of DNA:RNA hybrids and triplex helices in many essential functions in cells, this study's main aim is to detect benzothiazolebased moieties with selective binding or spectroscopic response to these nucleic structures compared to regular (non-hybrid) DNA and RNA duplexes and single-stranded forms. Complexes of nucleic acids and benzothiazoles, selected by this method, were characterized by UV/Vis, fluorescence and circular dichroism (CD) spectroscopy, isothermal titration calorimetry, and molecular modeling. Two compounds (1 and 6) from groups 1 and 2 demonstrated the highest affinities against 13 nucleic acid structures, while another compound (5) from group 2, despite lower affinities, yielded higher selectivity among studied compounds. Compound 1 significantly inhibited RNase H. Compound 6 could differentiate between B- (binding of $\mathbf{6}$ dimers inside minor groove) and A-type (intercalation) helices by an induced CD signal, while both $\mathbf{5}$ and $\mathbf{6}$ selectively stabilized ATT triplex in regard to AT duplex. Compound 3 induced strong condensation-like changes in CD spectra of AT-rich DNA sequences.
\end{abstract}

Keywords: benzothiazoles; competition dialysis; DNA:RNA hybrids; ATT triplex; circular dichroism spectroscopy; RNase H

\section{Introduction}

Nucleic acids are molecular targets for many drugs in cancer therapy due to their essential functions in cells (replication, transcriptional and translational regulation, and enzymatic reactions) [1]. Nucleic acid structures present a wide variety of shapes with varying major and minor groove widths that can be recognized by small molecules using a non-specific (mainly electrostatic) binding along the nucleic acid exterior, a specific groove binding, and intercalation (insertion of planar aromatic molecules between base pairs) [2].

Many studies have been directed towards the rational design of small molecules that will selectively recognize multistranded structures of nucleic acids, such as triplexes [2-7].

In most cases, triplexes in solution contain conformational features that are intermediate between A- and B-form. The parallel- or pyrimidine-motif (Py) has a C- or T-rich 
third strand bound in a parallel orientation to the duplex homopurine strand, while the antiparallel- or purine-motif $(\mathrm{Pu})$ has the opposite orientation and a primarily $\mathrm{A}$ - or $\mathrm{G}$-rich third strand $[8,9]$.

Specific ligands can stabilize triple helices through intercalation. For example, it has been demonstrated that ethidium bromide stabilizes polydA-2polydT (ATT) with $\mathrm{T} \cdot \mathrm{A} \times \mathrm{T}$ triplets, while benzopyridoindole derivatives can stabilize triple helices containing both $\mathrm{T} \cdot \mathrm{A} \times \mathrm{T}$ and $\mathrm{C} \cdot \mathrm{G} \times \mathrm{C}^{+}$base triplets [3]. The targeting of triplexes has recently been the focus of the antigene strategy for gene regulation. [10] The ability to target specific genes to modulate their structure and/or function in the genome has far-reaching implications in biology, biotechnology, and medicine (Figure 1) [11-15].

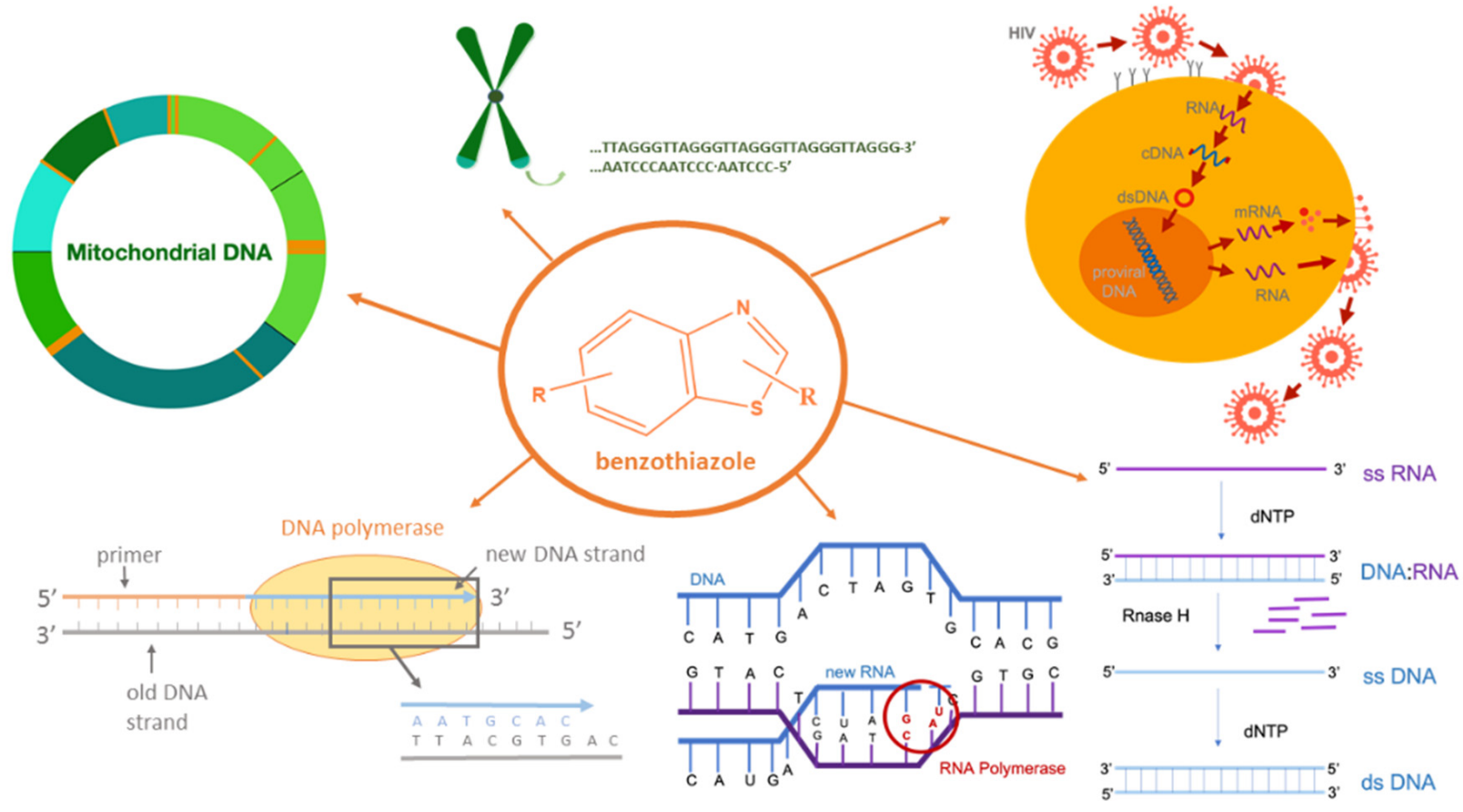

Figure 1. Potential biological activities of benzothiazole compounds.

DNA:RNA hybrids are formed as intermediate structures during many biologically important processes, such as DNA replication, transcription, and telomere replication and replication of HIV by reverse transcription (Figure 1) [16-20]. They can also form R-loops that have been detected in various organisms from bacteria to mammals and play crucial roles in regulating gene expression, DNA and histone modifications, immunoglobulin class switch recombination, DNA replication, and genome stability [21]. Small organic molecules with the ability to selectively inhibit DNA replication via Okazaki fragments, thus also blocking transcription, have a great potential in treating cancer because the replication is often accelerated in cancer cells (Figure 1). In addition, small molecules selective for hybrid duplexes have potential therapeutic applications as telomerase and RNaseH inhibitors [22-25].

There are few examples in the literature dedicated to the discovery of compounds that selectively bind to DNA:RNA hybrids [26-28]. Literature sources point to the existence of a small number of ligands with selective binding to DNA:RNA hybrids [26,27,29-31].

In thorough studies of Arya and Chaires, a common structural motif that preferentially binds to the hybrid structures was identified employing rapid screening assays, the competition dialysis, and thermal denaturation of mixtures [26,27,29,31-33]. Several compounds containing the common motif-planar aromatic ring system with a "bay" region, such as ethidium bromide, coralyne, aminoglycoside, propidium, thiazole orange and ellipticine, demonstrated preferential binding to hybrid duplexes, among other nucleic acid structures. 
As the benzothiazole structure also meets this criterion of the common motif, we have chosen for this study nine benzothiazole derivatives, synthesized by Racane et al., [34-36], which demonstrated high antiproliferative activity on a panel of cancer cell lines.

The main aim of this study was the detection of benzothiazole structure/s with preferential binding or spectroscopic response to DNA:RNA hybrids and ATT triplex in regard to regular (non-hybrid) DNA and RNA duplexes and single-stranded forms. Further, the mode of binding of selected ligands to DNA and RNA structures was determined using spectroscopic and calorimetric methods and molecular modeling. In this way, the mechanism of their antiproliferative activity [34-36] can be additionally clarified.

\section{Materials and Methods}

\subsection{Spectroscopy Measurements}

The UV/Vis spectra were recorded on a Varian Cary 100 Bio spectrophotometer (Agilent, Santa Clara, CA, USA), CD spectra on JASCO J815 spectrophotometer (ABL\&E Handels $\mathrm{GmbH}$, Wien, Austria) and fluorescence spectra on a Varian Cary Eclipse spectrophotometer (Agilent, Santa Clara, CA, USA) at $25^{\circ} \mathrm{C}$ using appropriate $1 \mathrm{~cm}$ path quartz cuvettes. Absolute quantum yields were determined using software implemented with the instrument by the Integrating sphere SC-30 of the Edinburgh FS5 spectrometer in the quartz cuvette of a $10 \mathrm{~mm}$ path length, to avoid the scattering of incident light at the liquid-air interface, and testing solutions with a $2 \mathrm{~mL}$ volume were used. For ITC titrations, MicroCal $^{\text {TM }}$ VP-ITC (MicroCal, Inc., Northampton, MA, USA) was used.

Polynucleotides were purchased as noted: poly rA, poly $\mathrm{rU}$, poly dA, poly dT, poly rA-poly $\mathrm{rU}$, poly $(\mathrm{dAdT})_{2}$, poly $\mathrm{dA}$ - poly $\mathrm{dT}$, poly $(\mathrm{dGdC})_{2}$, and calf thymus (ct)-DNA (Sigma-Aldrich, St. Louis, MI, USA), and they were dissolved in Na-cacodylate buffer, $I=0.05 \mathrm{~mol} \mathrm{dm}^{-3}, \mathrm{pH}=7$. According to the manufacturer's instructions, the average length of polynucleotides in base pairs is $\geq 500$. The calf thymus (ct)-DNA was additionally sonicated and filtered through a $0.45 \mathrm{~mm}$ filter [37]. Oligonucleotides (26-mers) were purchased as noted: oligo dA and oligo dT (Integrated DNA Technologies, Coralville, IA, USA) and dissolved in Na-cacodylate buffer, $\mathrm{I}=0.05 \mathrm{~mol} \mathrm{dm}^{-3}, \mathrm{pH}=7$. The DNA:RNA hybrid structures, DNA and RNA triplex, were prepared by mixing the two or three constitutive strands in sodium cacodylate buffer $\left(I=0.05 \mathrm{~mol} \mathrm{dm}^{-3}, \mathrm{pH}=7\right)$ with the addition of $\mathrm{NaCl}(0.05 \mathrm{M})$ and $1 \mathrm{mM}$ EDTA, heating to $90^{\circ} \mathrm{C}$ for $15^{\prime}$, and slow cooling to $10{ }^{\circ} \mathrm{C}$. RNase $\mathrm{H}$ from Escherichia coli $\mathrm{H} 560$ pol A1 was obtained from Roche/Merck in $25 \mathrm{mM}$ Tris- $\mathrm{HCl}, 50 \mathrm{mM} \mathrm{KCl}, 1 \mathrm{mM}$ dithiothreitol, $0.1 \mathrm{mM}$ EDTA, 50\% glycerol $(v / v)$,

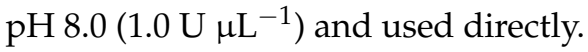

Polynucleotide concentration was determined spectroscopically as the concentration of phosphates [38]. Spectrophotometric titrations were performed at $\mathrm{pH}=7$ by adding portions of polynucleotide solution into the solution of the studied compound for fluorimetric experiments, and CD experiments were done by adding portions of the compound stock solution into the solution of the polynucleotide. Even though most of the spectroscopic titrations were performed in sodium cacodylate buffer, $I=0.05 \mathrm{~mol} \mathrm{dm}^{-3}$, there are a few exceptions, such as a fluorimetric experiment of 6 with poly $\mathrm{dA}$ - poly $\mathrm{rU}(\mathrm{pH}=7$, sodium cacodylate buffer, $I=0.2 \mathrm{~mol} \mathrm{dm}^{-3}$, and $1 \mathrm{mM}$ EDTA) and with ATT ( $\mathrm{pH}=7$, sodium cacodylate buffer, $I=0.05 \mathrm{~mol} \mathrm{dm}^{-3}$, and $1 \mathrm{mM}$ EDTA). For CD experiments, the exceptions are all titrations with ATT triplex and poly $\mathrm{rA}$ - poly dT hybrid $(\mathrm{pH}=7$, sodium cacodylate buffer, $I=0.05 \mathrm{~mol} \mathrm{dm}^{-3}$, and $1 \mathrm{mM}$ EDTA) and titration with poly dA-poly $\mathrm{rU}\left(\mathrm{pH}=7\right.$, sodium cacodylate buffer, $I=0.2 \mathrm{~mol} \mathrm{dm}^{-3}$, and $1 \mathrm{mM}$ EDTA). Emission was collected in the range $\lambda_{\mathrm{em}}=350-600 \mathrm{~nm}$. Values for $K_{\mathrm{s}}$ were obtained by processing titration data using the Scatchard [39] equation, all have satisfactory correlation coefficients $(>0.99)$. Thermal melting curves for DNA, RNA, the 4 polynucleotide mix (from melting of mixtures experiment), and their complexes with studied compounds were determined as previously described by following the absorption change at $260 \mathrm{~nm}$ as a function of temperature [30]. The absorbance of the ligands was subtracted from every curve and the absorbance scale was normalized. $T_{\mathrm{m}}$ values are the midpoints of the transition curves determined from the 
maximum of the first derivative and checked graphically by the tangent method. The $\Delta T_{\mathrm{m}}$ values were calculated by subtracting the $T_{\mathrm{m}}$ of the free nucleic acid from the $T_{\mathrm{m}}$ of the complex. Every $\Delta T_{\mathrm{m}}$ value here reported was the average of at least two measurements. The error in $\Delta T_{\mathrm{m}}$ is $\pm 0.5^{\circ} \mathrm{C}$.

For competition dialysis assay 13 different nucleic acid structures are used; each is placed in a separate Slide-A-Lyzer ${ }^{\circledR}$ MINI dialysis unit, then in a flotation dialysis unit (Pierce Chemical Company, Dallas, TX, USA), and finally into a glass container, where it was dialyzed against a common ligand solution (concentration of a compound in solution is $5 \mu \mathrm{M}$ ) for $24 \mathrm{~h}$ at $25^{\circ} \mathrm{C}$. [40] When dialysis equilibrium is reached, the samples are pipetted from the dialysis unit to 96-well plate reader (Greinder) and SDS is directly added to dissociate bounds. Concentrations are determined by fluorescence on the Tecan microplate reader and visualized in Origin.

RNase $\mathrm{H}$ assay was performed on a Varian Cary 100 Bio spectrophotometer at $37^{\circ} \mathrm{C}$ using $1 \mathrm{~cm}$ path quartz cuvettes for 1-3 h. The reaction buffer was $50 \mathrm{mM}$ Tris $\mathrm{pH} 8.0$, $50 \mathrm{mM} \mathrm{NaCl}$, and $10 \mathrm{mM} \mathrm{MgCl}_{2}$. Portions of compounds were added into the solution of the polynucleotide in glass cuvettes to achieve the desired experimental concentrations, then equilibrated at $0-4{ }^{\circ} \mathrm{C}$ for at least $12 \mathrm{~h}$ before use. After that, the polynucleotide (or compound-polynucleotide) solution was equilibrated at $37^{\circ} \mathrm{C} ; 2 \mu \mathrm{L}$ of Rnase $\mathrm{H}$ was added directly and the reaction mixture mixed by gentle inversion 12 times. The sample was placed in the spectrophotometer block at $37^{\circ} \mathrm{C}$ and $\mathrm{A}_{260}$ monitored for $1-3 \mathrm{~h}$ following an initial 2 min delay.

\subsection{ITC Measurements}

ITC experiments were performed using an isothermal titration microcalorimeter Microcal VP-ITC (MicroCal, Inc., Northampton, MA, USA) at $25.0{ }^{\circ} \mathrm{C}$. Origin 7.0 software, supplied by the manufacturer, was used for data acquisition and treatment. In the titration experiments, aliquots of the ligand (see Supplementary Materials for detailed protocol) were injected from a rotating syringe $(220 \mathrm{rpm})$ into the calorimeter reaction cell containing the polynucleotide solution. The spacing between each injection was $600 \mathrm{~s}$ and the initial delay before the first injection was $2000 \mathrm{~s}$. Blank experiments were carried out to determine the heats of the dilution of the ligands and the polynucleotides. All solutions used in the ITC experiments were degassed under vacuum before use to eliminate air bubbles. Each injection generated a heat burst curve (P in $\mu \mathrm{W}$ versus time). The data were imported to Origin 7.0 and the area under each peak was determined by integration to evaluate the heat associated with the injection. The data were corrected for heats of dilution. The resulting data were analyzed by using the Origin 7.0 software according to the model based on a single set or two sets of identical binding sites to estimate the binding constants $\left(K_{\mathrm{a}}\right)$, the binding stoichiometry $(\mathrm{N})$, and the enthalpy of binding $\left(\Delta_{\mathrm{r}} H^{\circ}\right)$. The reaction Gibbs energies $\left(\Delta_{\mathrm{r}} G^{\circ}\right)$ were calculated by using the following equation: $\Delta_{\mathrm{r}} G^{\circ}=-R T \ln \left(K_{\mathrm{a}}\right)$. Entropic contribution to the binding Gibbs energy was calculated by the equation: $T \Delta_{\mathrm{r}} S^{\circ}=\Delta_{\mathrm{r}} H^{\circ}-\Delta_{\mathrm{r}} G^{\circ}$.

\subsection{Molecular Modeling}

ATT molecule was built using the structure of the triplex available in PDB with PDB_id 1d3x wherein, for the purpose of modeling, CYT and GUA were replaced by THY and ADE. The obtained molecule was parametrized within OL15 and BSC1 [41] force fields and minimized. ATT-ligand complexes were built in program Pymol [42]. The complexes were placed in the center of the octahedral box filled with TIP3P type water molecules [43]. A water buffer of $11 \AA$ was used and $\mathrm{Na}^{+}$ions were added to neutralize the systems. The solvated complexes were geometry optimized in 3 cycles using the steepest descent and conjugate gradient methods. After optimization, systems were equilibrated for 0.5 ns in two steps: during the first step of 50 ps, the system was heated from 0 to $300 \mathrm{~K}$ under NVT conditions. In the next step, the water density was adjusted (NPT conditions). The equilibrated systems were subjected to the 200 ns of productive, unconstrained MD simulations at a constant temperature $(300 \mathrm{~K})$ and pressure $(1 \mathrm{~atm})$ with the time step of 
$2 \mathrm{fs}$ (SHAKE algorithm was used to restrain the motion of hydrogens). The simulations were performed with the pmemd program, available within the AMBER16 package, using periodic boundary conditions, wherein the electrostatic interactions were calculated using the particle-mesh Ewald (PME) method [44]. The temperature and pressure was regulated using Langevin thermostat [45] (with collision frequency of $1 \mathrm{ps}^{-1}$ ) and the Berendsen barostat [46], respectively.

\section{Results and Discussion}

\subsection{Characterization of Compounds in Aqueous Medium}

This study included nine cationic compounds: bis-benzothiazolyl-pyridines (1-3, group 1), 2-thienyl/2-benzothienyl-substituted 6-(2-imidazolinyl)benzothiazoles (4-6, group 2), and 2-aryl/heteroaryl-substituted 6-(2-imidazolinyl)benzothiazoles (7-9, group 3) (Scheme 1). All compounds were soluble $\left(c=5 \times 10^{-3} \mathrm{~mol} \mathrm{dm}^{-3}\right)$ in redistilled water or aqueous buffer (sodium cacodylate $/ \mathrm{HCl}$ buffer, $I=0.05 \mathrm{~mol} \mathrm{dm}^{-3}$ ). Buffered solutions of studied compounds were stable for more days. The absorbancies of studied compounds (Supplementary Materials) were proportional to their concentrations up to $c=2 \times 10^{-5} \mathrm{~mol} \mathrm{dm}^{-3}$. Linear changes in absorption with the increase of concentration indicate that studied compounds do not aggregate by intermolecular stacking at the experimental conditions used. Emission, absorption maxima, and the corresponding molar extinction coefficients $(\varepsilon)$ of all studied compounds are summarized in Table 1. The excitation spectra correspond to compounds absorption spectra in the area where emission and excitation spectrum do not overlap (Supplementary Materials).<smiles></smiles>

$1-3$<smiles>[R]c1nc2ccc(C3=NCCN3)cc2s1</smiles>

4 - 9 group 1

$\mathbf{R}$<smiles>[Li]c1cncc(S)c1</smiles><smiles>[2H]c1cccnc1S</smiles><smiles></smiles>

group 2

$\mathbf{R}$<smiles>[As]=Cc1cc(Br)cs1</smiles><smiles>S=[SH]c1ccc(-c2cccs2)s1</smiles><smiles>O=[SH]c1sc2ccccc2c1Cl</smiles>

group $\underline{3}$

$\mathbf{R}$<smiles>[3H]SCc1ccc2ccccc2c1</smiles><smiles>[B]S(=[B])c1cc2ccccc2o1</smiles><smiles>O=[SH](=S)c1ccc2[nH]ccc2c1</smiles>

Scheme 1. Structures of benzothiazole derivatives. 
Table 1. Electronic absorption data ${ }^{a}$, absorption maxima, and fluorescence data of benzothiazoles 1-9.

\begin{tabular}{|c|c|c|c|c|c|}
\hline Compd & $\begin{array}{c}\text { UV/Vis } \\
\lambda_{\max }(\mathrm{nm})\end{array}$ & $\begin{array}{c}\varepsilon \times 10^{3} \\
/ \mathrm{mmol}^{-1} \mathrm{~cm}^{2}\end{array}$ & $\begin{array}{l}\text { Emission } \\
\text { (nm) }\end{array}$ & $\begin{array}{l}\text { Stokes Shift } \\
\quad \times 10^{-18} \mathrm{~J}\end{array}$ & $\Phi_{\mathrm{f}}{ }^{\mathrm{c}}$ \\
\hline 1 & 330 & 32.1 & 379 & 4.1 & 0.06 \\
\hline 2 & $285 / 320^{b}$ & $31.7 / 20.6$ & 450 & $1.2 / 1.5$ & 0.13 \\
\hline 3 & 330 & 30.7 & 385 & 3.6 & 0.13 \\
\hline 4 & 343 & 44.9 & 416 & 2.7 & 0.37 \\
\hline 5 & 391 & 77.9 & 497 & 1.9 & 0.69 \\
\hline 6 & 342 & 25.1 & 430 & 2.3 & 0.20 \\
\hline 7 & 325 & 35.4 & 444 & 1.7 & 0.38 \\
\hline 8 & 355 & 36.6 & 430 & 2.6 & 0.54 \\
\hline 9 & 343 & 24.2 & 442 & 2.0 & 0.11 \\
\hline
\end{tabular}

a Sodium cacodylate buffer, $I=0.05 \mathrm{~mol} \mathrm{dm}^{-3}, \mathrm{pH}=7.0 ;{ }^{\mathrm{b}}$ in fluorescence titrations $\lambda_{\max }$ was $320 \mathrm{~nm}$; ${ }^{\mathrm{c}}$ Absolute fluorescence quantum yield was determined by integrating sphere SC-30, Edinburgh Inst., for argon-purged solutions; $\mathrm{QY} \pm 0.5^{\circ} \mathrm{C}$. [47].

\subsection{Study of Interactions of Benzothiazoles with Nucleic Acids in Aqueous Medium}

\subsubsection{Competition Dialysis Assay with 1-9}

Competition dialysis assay is a potent and valuable quantitative tool for examining compounds of interest that recognize selective structure/sequence of nucleic acid. In this method, an array of nucleic acid sequences and structures is used. Each is placed in a separate MINI dialysis unit fixed in a flotation dialysis supporter inside a glass container and dialyzed against a ligand solution. The free ligand solution is the same for all the structures, but when equilibrium is reached, each of the structure will bind the ligand according to its binding affinity $[29,40]$.

Nine previously synthesized [34-36] benzothiazole compounds with structural changes (Figure 2) in position 2 of the imidazole-based benzothiazole core were used to determine the effect of these modifications on the ability of compounds to interact with different DNA and RNA structures.

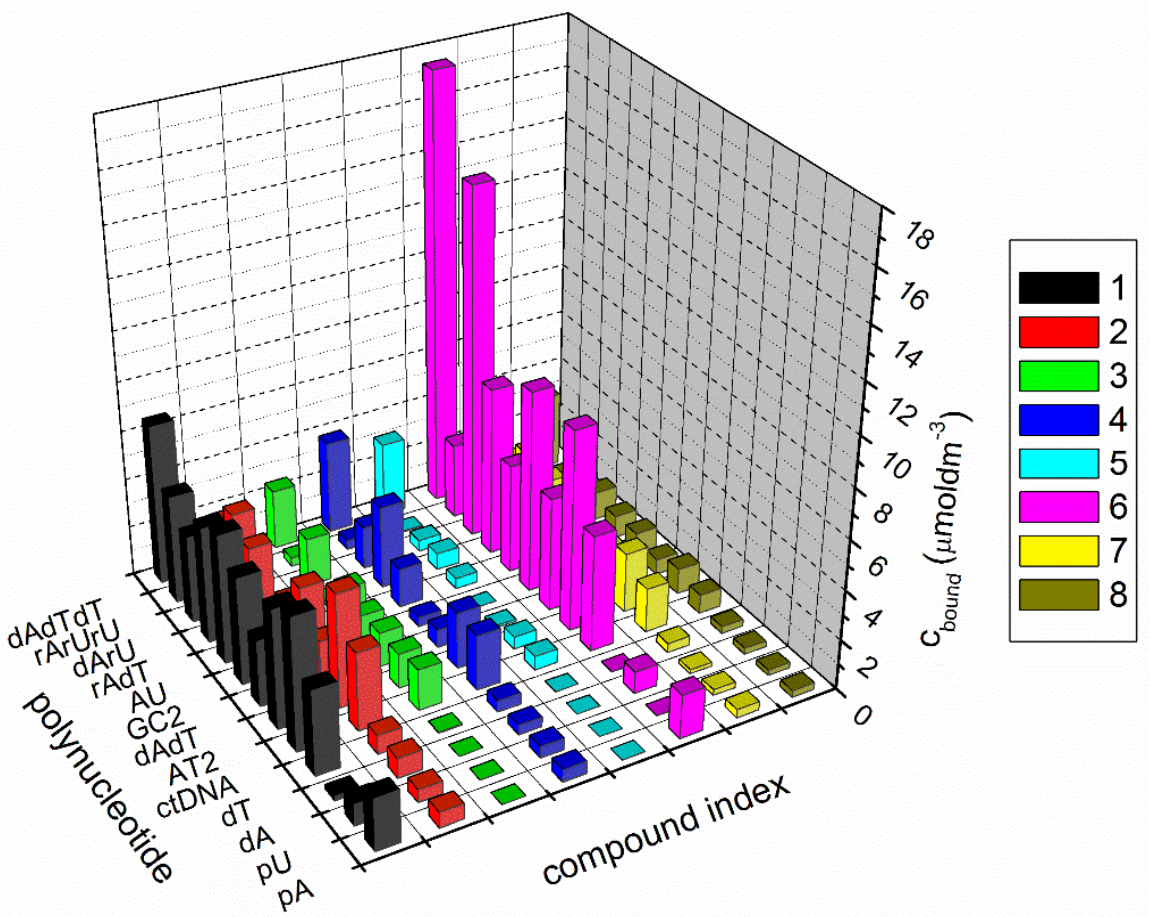

Figure 2. Summary of competition dialysis results with eight compounds binding to 13 nucleic acid structures and sequences ( $c_{\text {bound }}=$ concentration of ligand bound to each nucleic acid in $\mu \mathrm{M}$ ); sodium cacodylate buffer, $I=0.05 \mathrm{~mol} \mathrm{dm}{ }^{-3}, \mathrm{pH}=7$, and $+1 \mathrm{mM}$ EDTA. 
However, the interaction of eight compounds with 13 different nucleic acid structures was studied (Figure 2): single-stranded and double-stranded polynucleotides, DNA:RNA hybrids, and DNA and RNA triplexes. The interactions of compound 9 with polynucleotides were not further characterized, as compound $\mathbf{9}$ aggregated in the aqueous solution during the experiment.

The interaction of compounds with double-stranded polynucleotides depended on the base composition and secondary structure. Mostly, compounds demonstrated strong binding to DNA triplex ATT. Especially for 5, and even more so, 6, where binding with ATT triplex was stronger than with the double-stranded DNA, RNA, and DNA:RNA hybrids. As the amount of ligand bound to each nucleic acid structure $\left(C_{\text {bound }}\right)$ is directly proportional to the ligand binding affinity, it is clear that $\mathbf{1}$ and $\mathbf{6}$ displayed the highest affinities toward the majority of the nucleic acid structures. Regarding DNA:RNA hybrids, $\mathbf{6}$ demonstrated the strongest binding to poly $\mathrm{dA}$ - poly $\mathrm{rU}$, while $\mathbf{1}$ bound slightly better to poly $\mathrm{rA}$ - poly $\mathrm{dT}$ than to poly $\mathrm{dA}$ - poly rU. Only $\mathbf{1}$ demonstrated preferential binding to single-stranded poly dT, while both 1 and 6 exhibited stronger binding to poly $\mathrm{rA}$.

Two metrics were used, the specificity sum, $S S$ and the ratio $C_{\max } / \mathrm{SS}$, to gain information about the structural selectivity and compound affinity. To calculate the specificity sum, the binding data first need to be normalized relative to the maximal amount bound $\left(C_{\max }\right)$ to any of the structures in this assay. Then normalized amounts for each nucleic acid structure in the assay were simply summed. As 13 nucleic acid structures were used in this experiment, the SS ratio can range from 1, which denotes the binding to only one nucleic acid structure, to 13, which means an equal binding to all structures. According to Figure 3, the best structural selectivity demonstrated $\mathbf{5}$ and $\mathbf{6}$. Values for the specificity sum for all studied compounds are shown in Figure 3.

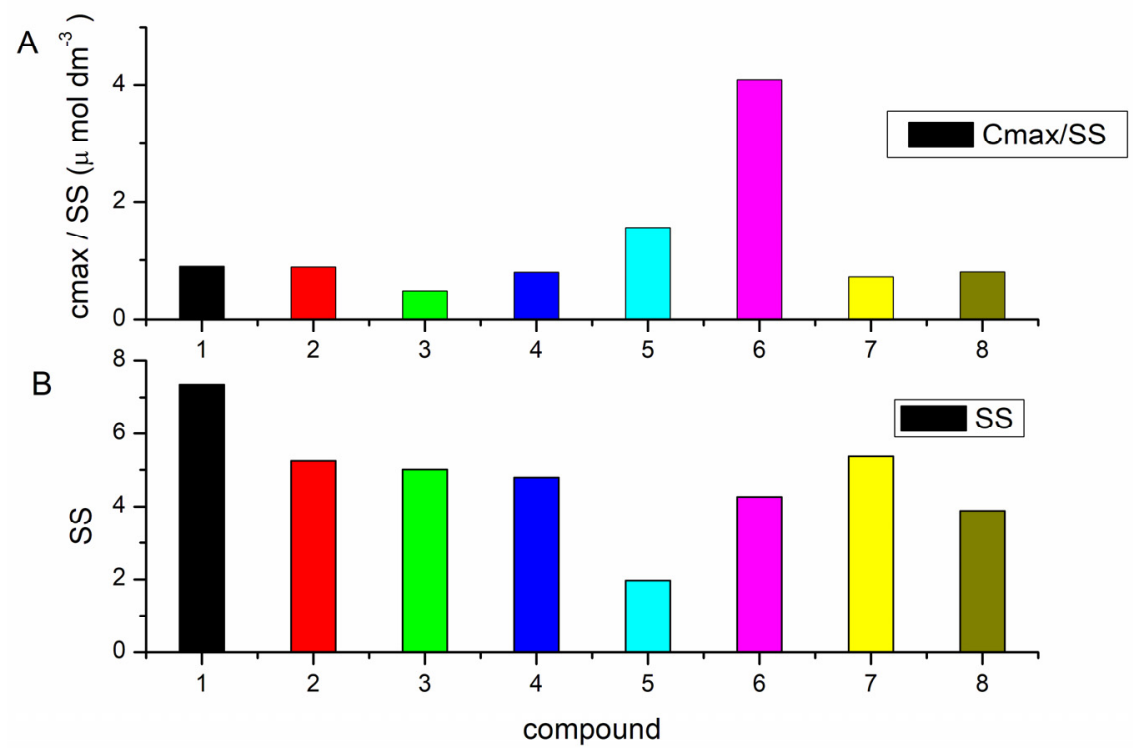

Figure 3. Ratio $c_{\max } / \mathrm{SS}$ (A) and specific sum SS (B) for 8 benzothiazole compounds.

Ratio $\mathrm{C}_{\max }$ /SS refers to both affinity and selectivity. This ratio is directly proportional to binding affinity. Thus, if $\mathrm{C}_{\max }$ is large (high binding affinity) and SS is small (high selectivity), a high value of $C_{\max } / S S$ will be obtained and vice versa $[29,40]$.

Identification of compounds with the best-combined selectivity and affinity can be obtained by comparison of SS and $C_{\max } / S S$ values. Based on these metrics, 5 and $\mathbf{6}$ were identified as compounds with the greatest combined selectivity and affinity. Despite the largest SS value, $\mathbf{1}$ was also selected for further characterization with polynucleotides, as it demonstrated relatively higher $C_{\text {bound }}$ values (amount of ligand bound to each nucleic acid structure), determined for ds- and triplex polynucleotides than other compounds. All three compounds demonstrated selectivity for ATT triplex. Additionally, 6 exhibited 
the highest affinity toward poly $\mathrm{dA}$ - poly $\mathrm{rU}$, while $\mathbf{1}$ displayed a higher affinity toward poly rA-poly dT.

\subsubsection{Fluorescence Spectroscopy and Isothermal Titration Calorimetry}

Isothermal titration calorimetry and fluorescence spectroscopy have been used to characterize the ligand binding to nucleic acid structures [48,49]. According to the results of the competition dialysis assay (affinities and selectivities), several complexes were selected for detailed characterization: 1-ATT (Figure 4), 1-poly rA-poly dT, 6-ATT, 6-poly dA-poly rU, and 5-ATT (Table 2).

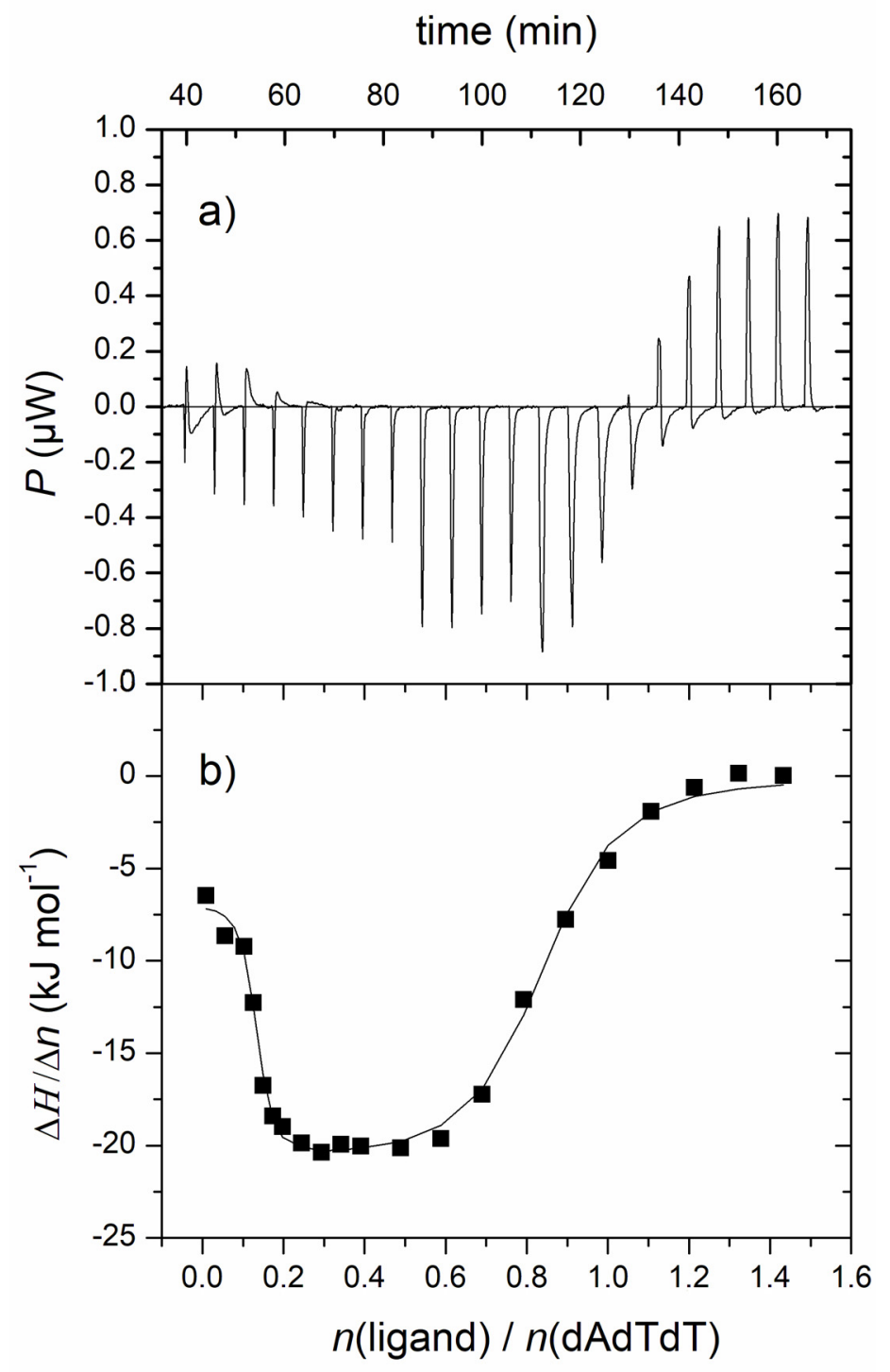

Figure 4. (a) Raw titration data from the single injection of $\mathbf{1}$ into a solution of ATT triplex; (b) ITC experiment of ATT triplex titrated with 1; experimental data $(\boldsymbol{\square})$ and calculated fit (-) for model of two sets of sites. $\left[\right.$ ATT] $=3.0 \times 10^{-5} \mathrm{M} ; \mathrm{pH}=7.0$, Na-cacodylate buffer, $I=0.05 \mathrm{~mol} \mathrm{dm}^{-3}+1 \mathrm{mM}$ EDTA.

Binding affinities of 5 and $\mathbf{6}$ could not be calculated by ITC titrations due to the aggregation of these compounds in the ITC method concentration range that interfered with obtaining reliable results. For $\mathbf{6}$, binding affinities were assessed by fluorescence spectroscopy, which enabled measurements in lower sample concentrations. The fluorescence changes of $\mathbf{5}$ in titration with ATT triplex were too small for the accurate calculation of the binding constant. 
Table 2. Data parameters obtained during nonlinear regression (model: one and two sets of sites) for ITC titration for 1-ATT, 1-poly rA-poly dT complex. Binding constants $(\log K s){ }^{\text {a }}$ and ratios $n$ a ([bound compound]/[polynucleotide phosphate]) calculated from the fluorescence titrations for ligand-nucleic acid complex ${ }^{\mathrm{d}}$.

\begin{tabular}{|c|c|c|c|c|c|}
\hline Complex & $n 1 / n 2$ & $\log K s_{1} / K s_{2}$ & $\Delta_{\mathrm{r}} \mathrm{H}_{1,2} / \mathrm{kJ} \mathrm{\textrm {mol } ^ { - 1 }}$ & $T \Delta_{\mathrm{r} 1,2} S^{\circ} / \mathrm{kJ} \mathrm{mol}^{-1}$ & $\Delta_{\mathrm{r}} G_{1,2} / \mathrm{kJ} \mathrm{mol}^{-1}$ \\
\hline \multirow[t]{2}{*}{ 1-ATT } & $0.7 / 0.1$ & $6.5 / 8.7$ & $-21.1 /-6.8$ & $15.7 / 43.3$ & $-36.8 /-50.1$ \\
\hline & $n$ & $\log K s$ & $\Delta_{\mathrm{r}} H^{\circ} / \mathrm{kJ} \mathrm{mol}^{-1}$ & $T \Delta_{\mathrm{r}} S^{\circ} / \mathrm{kJ} \mathrm{mol}^{-1}$ & $\Delta_{\mathrm{r}} G^{\circ} / \mathrm{kJ} \mathrm{mol}^{-1}$ \\
\hline 1-rA-dT & 0.1 & 7.8 & -6.3 & 38.4 & -44.7 \\
\hline 6-ATT ${ }^{\mathrm{b}}$ & 0.7 & 7.6 & $-c$ & $-c$ & $-c$ \\
\hline 6-dA-rU b & 0.8 & 8.0 & $-c$ & $-c$ & $-c$ \\
\hline
\end{tabular}

a Processing of titration data using Scatchard [39,50] equation gave values of ratio $n$ [bound compound]/[polynucleotide]; correlation coefficients were $>0.99$ for most of calculated Ks; accuracy of $n \pm 20 \%$, consequently $\log K s$ values vary in the same order of magnitude; ${ }^{\mathrm{b}} I / I_{0}$ for 6 -ATT and 6-poly dA-poly rU $=0.2$ and $0.3 ; I_{0}$-starting fluorescence intensity of compound; I-fluorescence intensity of compound/polynucleotide complex calculated by Scatchard $[39,50]$ equation; ${ }^{\mathrm{c}}$ Binding affinities were obtained by fluorescence spectroscopy.

d All measurements were done at $\mathrm{pH}=7.0$ (buffer sodium cacodylate, $I=0.05 \mathrm{~mol} \mathrm{dm}^{-3}$ ).

ITC titration experiments resulted in mostly negative peaks, indicating that the binding processes were exothermic (Figure 4). The resulting data for the 1-poly rA-poly dT complex was fitted to a single-site binding model, while data for 1-ATT was fitted to model two sets of sites by using a nonlinear least square method (Table 2). The analysis of ITC experiments of compound 1 with poly rA-poly dT and ATT triplex demonstrated high and similar binding affinities (log Ks, Table 2), which is consistent with the results from competitive dialysis assay.

Compound 1 demonstrated two types of binding in titration with ATT triplex (Figure 4). The first binding event was characterized by a higher binding constant than the second type of binding. The first binding event is an entropically guided process probably accompanied by the release of bound water molecules from the polynucleotide groove to the bulk [48]. The second type of binding, characterized by a higher ratio $\mathrm{N}$, is an enthalpy-driven process accompanied by an increase in the number of hydrogen bonds, aromatic stacking, electrostatic interactions, and van der Waals interactions, followed by a large favorable entropy contribution. The interaction of $\mathbf{1}$ with poly $\mathrm{rA}$-poly dT was, similar to its complex with ATT, characterized by positive (favorable) binding entropy and weak negative enthalpy (Table 2), indicating an entropically driven process.

The groove binding is usually entropically favorable and slightly endothermic, resulting from the release of relatively highly ordered water molecules surrounding the apolar surfaces to the bulk. The enthalpy contribution to the free energy is associated with the overall increase of bonding (hydrogen bonds, ionic, electrostatic and van der Waals interactions, and polarization of the interacting groups) [51].

An analysis of the fluorescence data of $\mathbf{6}$ with poly dA-poly rU and ATT polynucleotides gave high binding constants and rather high ratios, $\mathrm{N}$, for both complexes. Unlike 6, 5 induced small emission changes upon binding to ATT triplex, thus disabling calculation of the stability constant.

\subsubsection{Thermal Melting Experiments and RNase H Assay}

Thermal denaturation is an additional method for monitoring binding to nucleic acids [52]. Stabilization of nucleic acid structure induced by small molecules causes an increase in the melting temperature of that structure. In a typical experiment, a ligand is monitored against one nucleic acid structure at conditions close to the equimolar ligand/nucleic acid ratio. The melting of mixtures, a relatively straightforward extension of the typical thermal melting experiment design, enables an evaluation of the stabilization effect of the ligand against a number of different nucleic acid structures. If there is an excess of nucleic acid over the compound where the binding sites are not fully saturated, a preference toward sequence or structure can be established [40]. 
In this experiment, ligand selectivity was studied with a mixture of four different polynucleotides, DNA (poly dA-poly dT), RNA (poly rA-poly rU), and two DNA:RNA hybrids (poly rA-poly dT and poly dA-poly rU) (Figure 5, Table 3).

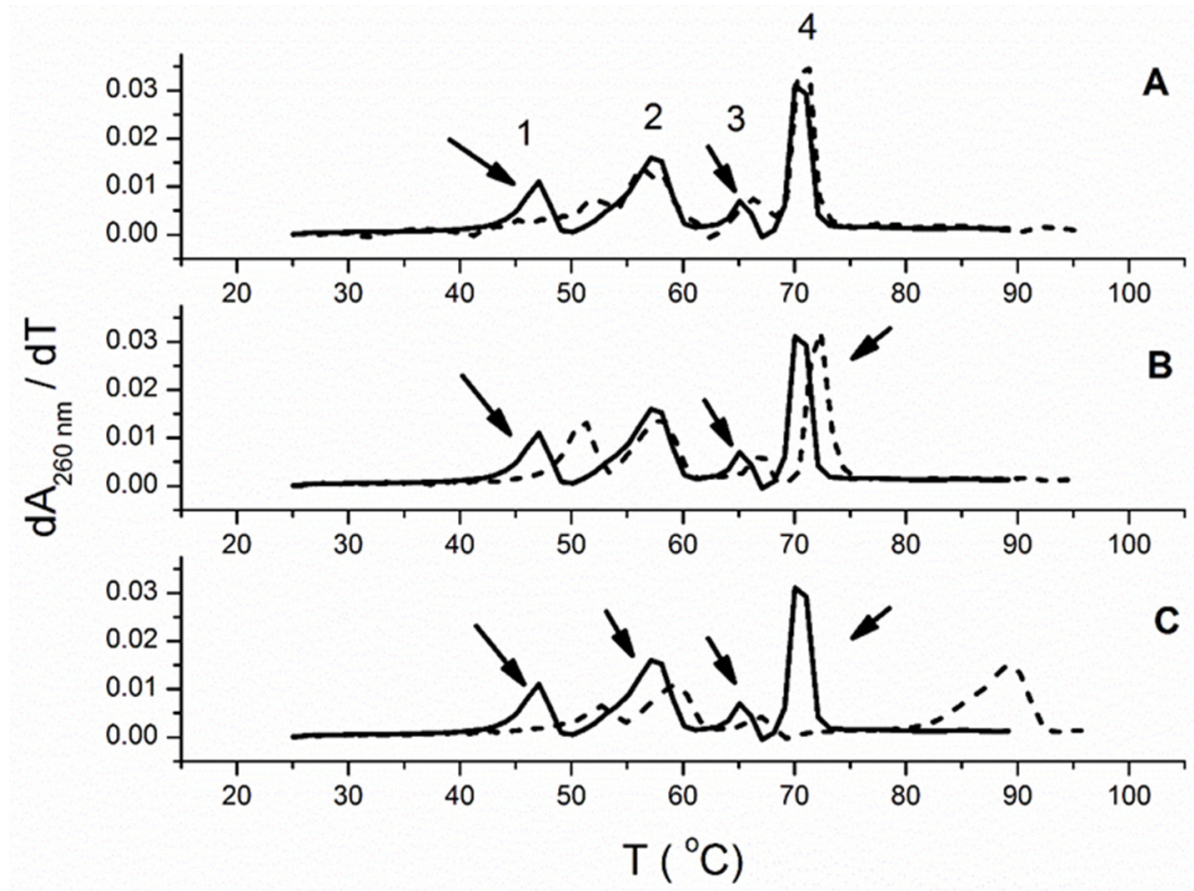

Figure 5. Melting profiles of polynucleotide mixtures (first derivative profile of absorbance versus temperature). Each panel shows the melting of a mixture of 4 polynucleotides: a DNA:RNA hybrid [poly dA-poly rU; peak 1], RNA [poly rA-poly rU; peak 2], an RNA:DNA hybrid [poly rA-poly $\mathrm{dT}$; peak 3] and DNA [poly dA-poly dT; peak 4] as the solid black line (-). The concentration of each polynucleotide structure was $20 \mu \mathrm{M}(\mathrm{bp})$; total polynucleotide concentration is $80 \mu \mathrm{M}(\mathrm{bp})$. The dashed line (- - ) in each panel shows the effect of the addition of ligand. (A) 6 (B) 5 (C) 1 all at $2 \mu \mathrm{M}$ (50 mM sodium cacodylate buffer, $50 \mathrm{mM} \mathrm{NaCl}$, and $1 \mathrm{mM}$ EDTA).

Table 3. The $\Delta T_{\mathrm{m}}{ }^{\text {a }}$ values $\left({ }^{\circ} \mathrm{C}\right)$ of studied mixture of four polynucleotides (poly rA-poly dT, poly $\mathrm{rA}$ - poly rU, poly dA-poly rU, and poly dA-poly dT) ${ }^{\mathrm{b}}$ upon addition of ratio $\mathrm{r}=0.025^{\mathrm{c}}$ of $\mathbf{1}, \mathbf{5}$, and $\mathbf{6}^{\mathrm{d}}$.

\begin{tabular}{cccc}
\hline & & $\Delta T_{\mathbf{m}}{ }^{\mathbf{a}}$ & \\
\hline Polynucleotide & $\mathbf{1}$ & $\mathbf{5}$ & $\mathbf{6}$ \\
poly dA-poly rU & 5.6 & 4 & 0.5 \\
poly rA-poly rU & 2.2 & 1 & 1.5 \\
poly rA-poly dT & 1.7 & 1.7 & 0 \\
poly dA-poly dT & 19.1 & 2.1 &
\end{tabular}

${ }^{\mathrm{a}} \Delta T_{\mathrm{m}}=T_{\mathrm{m}}$ (complex polynucleotide-dye) $-T_{\mathrm{m}}$ (polynucleotide); error in $\Delta T_{\mathrm{m}}: \pm 0.5^{\circ} \mathrm{C}^{\mathrm{b}} T_{\mathrm{m}}$ values for mixture of polynucleotides without compound, poly dA-poly $\mathrm{rU}=47^{\circ} \mathrm{C}$; poly $\mathrm{rA}$ - poly $\mathrm{rU}=57.4^{\circ} \mathrm{C}$; poly $\mathrm{rA}$ - poly dT $=65.3^{\circ} \mathrm{C}$; poly dA-poly $\mathrm{dT}=70.6{ }^{\circ} \mathrm{C} . ;{ }^{\circ} \mathbf{r}=$ [compound] $/$ [polynucleotide]. ${ }^{\mathrm{d}}$ All measurements were done at $\mathrm{pH}$ 7.0 (sodium cacodylate buffer with $\mathrm{NaCl}, I=0.1 \mathrm{~mol} \mathrm{dm}^{-3}+1 \mathrm{mM}$ EDTA).

The compounds $\mathbf{1}$ and $\mathbf{5}$ demonstrated the stabilization effect of all studied dspolynucleotides (Table 3, Figure 5). In addition, these two compounds demonstrated a better stabilization effect of poly $\mathrm{dA}$ - poly $\mathrm{rU}$ than of poly $\mathrm{rA}-$ poly $\mathrm{dT}$. Interestingly, among ds-nucleic structures, 6 almost exclusively stabilized poly dA-poly rU. It has been demonstrated that the stability of hybrid duplexes, composed of homopurine and homopyrimidine strands, depends on several factors, such as the percentage of deoxyribo(pyrimidine), i.e., $\mathrm{d}(\mathrm{Py})$ content in each of the strands, the oligomeric length and the percentage of $(\mathrm{A})_{n}$ :(T or $\mathrm{U})_{n}$ content [53]. Thus, for example, the hybrid duplex containing the DNA purine strand and the RNA pyrimidine strand $\mathrm{d}(\mathrm{Pu}): \mathrm{r}(\mathrm{Py})$, such as poly $\mathrm{dA}-$ poly $\mathrm{rU}$, demonstrates much 
less thermal stability compared to the $\mathrm{r}(\mathrm{Pu}): \mathrm{d}(\mathrm{Py})$ composition, such as poly $\mathrm{rA}-$ poly $\mathrm{dT}$. This could be a reason for the higher stabilization effect of dArU, in comparison to $\mathrm{AdT}$, induced by 1, 5, and $\mathbf{6}$. Among ds-polynucleotides, 1 demonstrated the most significant stabilization effect with poly $\mathrm{dA}$ - poly $\mathrm{rU}$ and especially poly $\mathrm{dA}$ - poly $\mathrm{dT}$ (Table 3 ). It should be emphasized that 1 possesses a higher number of net positive charges than 5 and $\mathbf{6}(\mathbf{1},+2$; $5,+1 ; 6,+1)$. However, only 6 demonstrated selective stabilization of the hybrid duplex, poly $\mathrm{dA}$ - poly $\mathrm{rU}$, in a mixture of double-stranded polynucleotides.

As all three ligands stabilized poly $\mathrm{rA}$ - poly $\mathrm{dT}$ and poly $\mathrm{dA}$ - poly $\mathrm{rU}$, we performed a spectrophotometric RNase $\mathrm{H}$ assay to evaluate the capability of 1, 5, and $\mathbf{6}$ to inhibit RNase H [29]. The cleaving of the RNA strand from a DNA:RNA hybrid duplex was followed by an increase in $\mathrm{A}_{260}$ (Figure 6).

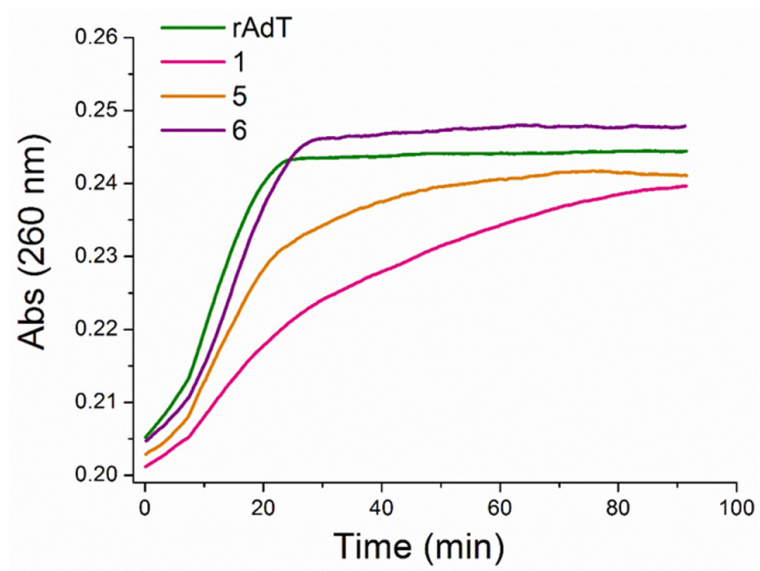

Figure 6. Inhibition of RNase H digestion of poly $\mathrm{rA}$ - poly dT by 1, 5, and 6; concentration of nucleic acid hybrid structure was $10 \mu \mathrm{M}(\mathrm{bp}) ; \mathbf{1}, \mathbf{5}$, and $\mathbf{6}$, all at $3 \mu \mathrm{M}$.

The best inhibition activity of the RNase $\mathrm{H}$ digestion of poly $\mathrm{rA}$ - poly dT demonstrated benzothiazole 1. The data from a thermal melting of polynucleotide mixtures show a good correlation with the results of the RNase $\mathrm{H}$ assay. The $\mathrm{RNase} \mathrm{H}$ assay was utilized here as an additional method to the thermal melting of polynucleotide mixtures. It provides information on which ligands can be biologically relevant as RNase $\mathrm{H}$ inhibitors and deserves detailed investigation regarding that.

The melting profile of free ATT in sodium cacodylate buffer ( $50 \mathrm{mM}$ sodium cacodylate buffer, $50 \mathrm{mM} \mathrm{NaCl}$, and $1 \mathrm{mM}$ EDTA) demonstrated biphasic transition (Figure 7, Table 4).
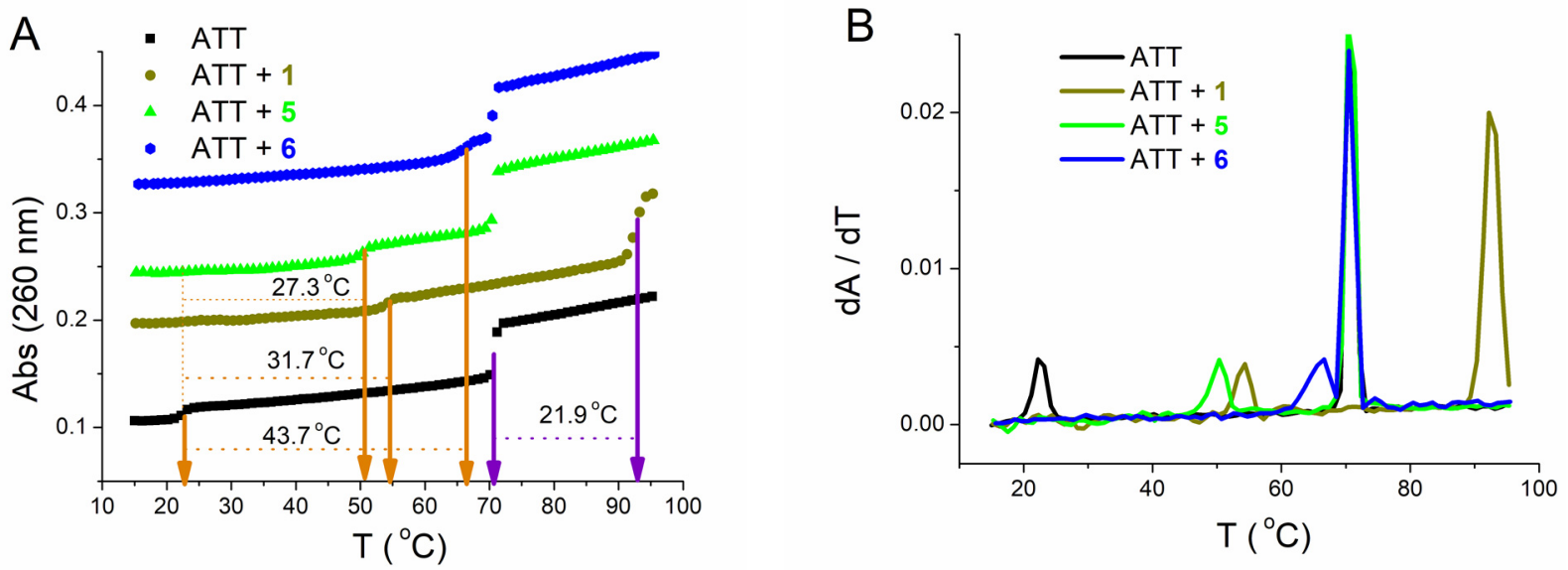

Figure 7. (A): Melting curve of ATT triplex upon addition of ratio, $\mathbf{r}$ ([compound/[polynucleotide]) $=0.1$ of $\mathbf{1}, \mathbf{5}$, and $\mathbf{6}$ at $\mathrm{pH}=7.0$ (sodium cacodylate buffer with $\mathrm{NaCl}, I=0.1 \mathrm{~mol} \mathrm{dm}^{-3}+1 \mathrm{mM}$ EDTA; orange arrows-first transition, violet arrows—-second transition); (B): First derivative of absorbance at $260 \mathrm{~nm}$ in dependence of temperature. 
Table 4. The $\Delta T_{\mathrm{m}}{ }^{\mathrm{a}}$ values $\left({ }^{\circ} \mathrm{C}\right)$ of ATT triplex ${ }^{\mathrm{b}}$ upon addition of ratio ${ }^{\mathrm{c}} \mathbf{r}=$ [compound] $/$ [polynucleotide] of 1,5 , and $6^{\mathrm{d}}$.

\begin{tabular}{cccccccccc}
\hline \multicolumn{10}{c}{$\Delta \boldsymbol{T}_{\mathbf{m}}{ }^{\mathbf{a}}$} \\
\hline & \multicolumn{10}{c}{$\mathbf{1}$} & & $\mathbf{5}$ & & $\mathbf{6}$ \\
\hline${ }^{\mathrm{c}} \mathbf{r}$ & 0.1 & 0.2 & 0.3 & 0.1 & 0.2 & 0.3 & 0.025 & 0.05 & 0.1 \\
\hline & $31.7 / 21.9$ & $32.5 / 23.9$ & - & $27.3 / 0$ & $30.1 / 0$ & $32.8 / 0$ & $36.7 / 0$ & $42.0 / 0$ & $43.7 / 0$ \\
\hline
\end{tabular}

${ }^{\mathrm{a}} \Delta T_{\mathrm{m}}=T_{\mathrm{m}}$ (complex polynucleotide-dye) $-T_{\mathrm{m}}$ (polynucleotide); error in $\Delta T_{\mathrm{m}}: \pm 0.5^{\circ} \mathrm{C} ;{ }^{\mathrm{b}} T_{\mathrm{m}}$ values for biphasic thermal denaturation profile of ATT without compound, $T_{\mathrm{m} 1}=22.6 ; T_{\mathrm{m} 2}=70.7 ;{ }^{\mathrm{C}} \mathbf{r}=$ [compound] $/$ [polynucleotide] d All measurements were done at $\mathrm{pH} 7.0$ (sodium cacodylate buffer with $\mathrm{NaCl}, I=0.1 \mathrm{~mol} \mathrm{dm}^{-3}+1 \mathrm{mM}$ EDTA).

The first transition was at $T_{\mathrm{m} 1}=22.6{ }^{\circ} \mathrm{C}$ and corresponds to dissociation of the third strand (poly dT with Hoogsteen base pairs from the major groove). The second transition was at $T_{\mathrm{m} 2}=70.7^{\circ} \mathrm{C}$ and corresponds to dissociation of Watson-Crick base pairs of doublestranded poly dA-poly dT [54,55]. Albeit 1 stabilized both the ATT triplex and poly dA-poly dT duplex, the higher stabilization effect was demonstrated with the ATT triplex. Unlike 1, 5 and $\mathbf{6}$ increased $T_{\mathrm{m} 1}$, while $T_{\mathrm{m} 2}$ did not change. Particularly interesting was compound 6, which stabilized ATT significantly even at very low ratios, $\mathbf{r}$ (Figure 7). Data from this experiment for poly dA-poly dT (Table 4) duplex agrees very well with those for the same polynucleotide obtained in the melting of mixtures experiment (Table 3).

\subsubsection{Circular Dichroism (CD) Experiments}

Based on competition dialysis results, we further proceeded with the characterization of selected complexes by CD spectroscopy. Electronic circular dichroism (ECD) is highly sensitive toward conformational changes in the helical structure of DNA and RNA and their complexes with small molecules [56,57]. In addition, an induced CD spectrum (ICD) that can arise from the interaction of achiral small molecules such as 1, 5, and $\mathbf{6}$ with nucleic acids, could be very informative of the binding modes. We monitored changes in CD spectra upon the interaction of $\mathbf{1}, \mathbf{5}$, and $\mathbf{6}$ with representatives of the B-helix family, ctDNA with a mixed base pair composition, and with poly dA - poly dT characterized by a much narrower and deeper minor groove in comparison to other common B-helices. As a model of A-helical structure, we used poly rA-poly rU (ds-RNA) characterized by a wide and shallow minor groove and deep and narrow major groove [58,59]. Interactions were also studied with two double-stranded DNA:RNA hybrids, poly dA-poly rU, and poly rA-poly dT and the DNA triple helix, ATT. While NMR, Raman, and X-ray fiber diffraction studies suggest B-like conformation for poly rA-poly dT in high humidity conditions, it seems that the global conformation of poly dA-poly $\mathrm{rU}$ is considerably more affected by the ribopyrimidine strand, resulting in an A-type helix closer in conformation to the A-form of RNA [60,61]. Further, NMR and IR data suggest that structural characteristics of triplexes resemble B-DNA much more than A-DNA [62-64].

The addition of $\mathbf{1}, \mathbf{5}$, and $\mathbf{6}$ to polynucleotides mainly caused a decrease of CD intensity of DNA and RNA polynucleotides at their maximal values (ctDNA at $275 \mathrm{~nm}$, AT-DNA, AU-RNA, and DNA:RNA hybrids at $260 \mathrm{~nm}$ ) (Figure 8); however, induced CD spectra of these compounds, which changed with increasing ratio, $r$, were more informational regarding their modes of binding.

At $\mathbf{r} \leq 0.1,6$ caused either negligible or weak negative ICD signals (around $320 \mathrm{~nm}$ ) with all polynucleotides (Supplementary Materials). However, at $\mathbf{r}>0.1$, this compound differentiates between B- and A-type helices by the mode of binding (Figure 8). Negative ICD signals support intercalation to A-type helices, poly $\mathrm{dA}$ - poly $\mathrm{rU}$ and poly $\mathrm{rA}$ - poly $\mathrm{rU}$, whereas an appearance of a bisignate $\mathrm{CD}$ signal implied the formation of 6 dimers most probably inside the minor groove of poly $\mathrm{rA}$ - poly $\mathrm{dT}$, poly $\mathrm{dA}$ - poly $\mathrm{dT}$, and ATT triplex. Interactions of $\mathbf{6}$ were additionally investigated with ATT 26mer by fluorimetric and $\mathrm{CD}$ spectroscopy to estimate the influence of the ATT polymer length on the binding strength. Processing of titration data gave ratio $n$ and binding constant $(\log K s=7.4$, 
$n=0.7$ ) comparable to that obtained with the ATT polynucleotide (Table 2). Regarding CD titration of 6 with ATT 26mer, a similar bisignate ICD signal, as in the CD titration with ATT polynucleotide, was noticed, suggesting that ATT polymer length did not influence the mode of binding (Supplementary Materials) [65].

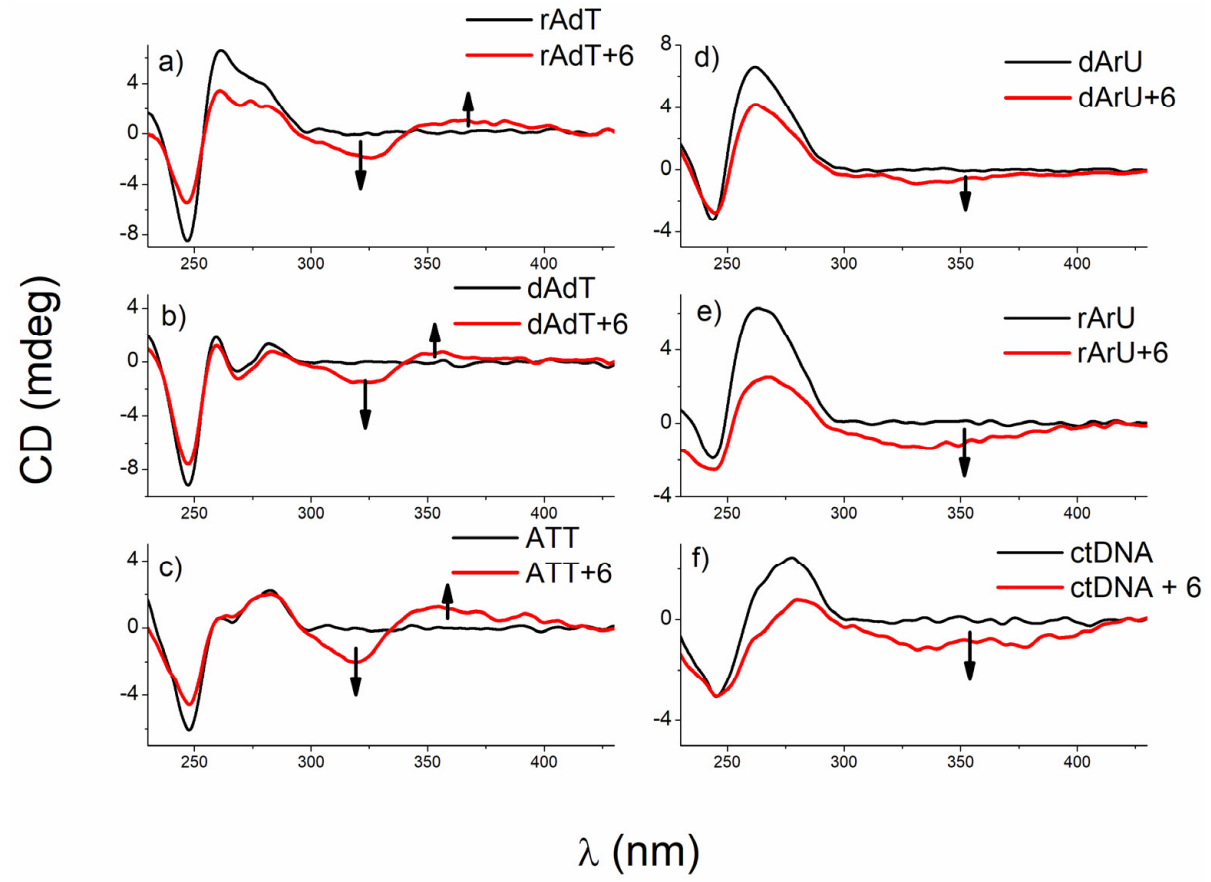

Figure 8. CD titrations of (a) poly $\mathrm{rA}$ - poly dT, (b) poly dA-poly dT, (c) ATT triplex, (d) poly $\mathrm{dA}$ - poly rU, (e) poly rA-poly rU, and (f) $\operatorname{ctDNA}\left(c=3.0 \times 10^{-5} \mathrm{~mol} \mathrm{dm}^{-3}\right)$ with 6 at molar ratios $\mathbf{r}$ $=[$ compound $] /$ [polynucleotide $]=0.3\left(\mathrm{pH}=7.0\right.$, buffer sodium cacodylate,$I=0.05 \mathrm{~mol} \mathrm{dm}^{-3}+1 \mathrm{mM}$ EDTA for all titrations except poly dA-poly rU $\left(I=0.2 \mathrm{~mol} \mathrm{dm}^{-3}+1 \mathrm{mM}\right.$ EDTA $)$ ).

Unexpectedly, 6 did not bind in the form of dimers to ctDNA (B-helix), instead, changes (negative ICD signals, Figure 8) were indicative for intercalation, which can probably be related to the composition of ctDNA containing $42 \%$ of GC basepairs beside AT base pairs.

Unlike 6, 5 did not differentiate among polynucleotide conformations (Supplementary Materials). Its addition caused a rise of bisignate ICD signals with all studied nucleic acid structures. Such an effect supports a formation of dimers (minor groove of ATT triplex and major groove of poly rA-poly $\mathrm{rU}$ ) or larger aggregates, similar to those observed with poly dA-poly dT and ctDNA.

On the other hand, bis-benzothiazolyl-pyridine 1, which is sterically more demanding compared to 5 and $\mathbf{6}$, provoked a strong positive ICD band (at $340 \mathrm{~nm}$ ) at $\mathbf{r} \leq 0.1$, implying binding within the minor groove of ctDNA, poly dA-poly dT, and ATT triplex (Figure 8). At ratios higher than $\mathbf{r}=0.1$, an excess of $\mathbf{6}$ molecules cannot accommodate inside the minor groove so well; instead, 6 forms aggregate along the polynucleotide backbones. Negative ICD signals (around $340 \mathrm{~nm}$ ) at $\mathbf{r} \leq 0.1$ point towards intercalative binding to poly rA-poly rU and both hybrids. An increase in ICD intensity with an increase of $\mathbf{r}(\mathbf{r}>0.1)$ suggests aggregation of $\mathbf{6}$ along the polynucleotide surfaces. Further, a clear isodichroic point $(\lambda=253 \mathrm{~nm}$ ) observed for 1 and poly rA-poly dT strongly suggests one dominant interaction mode of this compound with the DNA chiral axis.

Due to the strong interaction of 1 with the ATT triplex, we decided to examine interactions of this triplex with its regioisomer 3 to see whether the position of benzothiazoleimidazolinyl chains on pyridine ring affected them. Interestingly, compound 3, unlike its regioisomer 1, induced a strong increase in the intensity of CD spectra of ATT triplex, poly dA-poly dT, and ctDNA (ctDNA at $275 \mathrm{~nm}$, AT-DNA at 260 and $282 \mathrm{~nm}$, and ATT at $282 \mathrm{~nm}$ ) compared to the intrinsic CD bands of these polynucleotides, and in addition, strong positive ICD bands located around $350 \mathrm{~nm}$ (Figure 9, Supplementary Materials). 


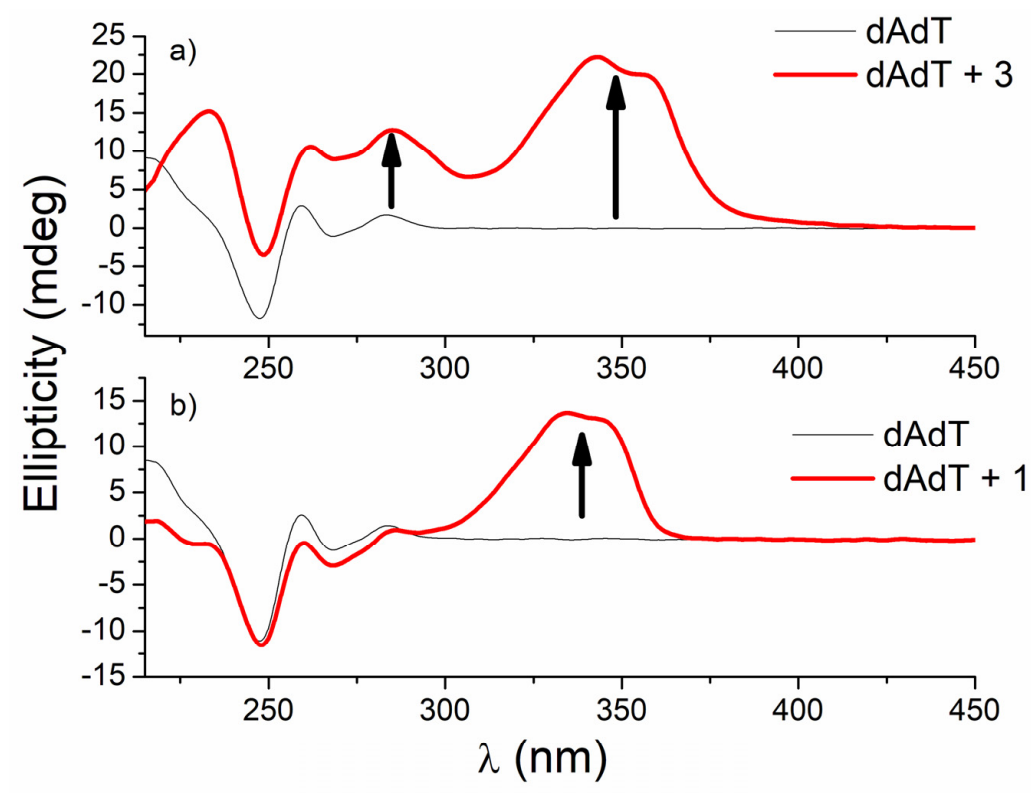

Figure 9. CD titrations of AT-DNA duplex (dAdT) $\left(c=3.0 \times 10^{-5} \mathrm{~mol} \mathrm{dm}^{-3}\right)$ with $\mathbf{3}(\mathbf{a})$ and $\mathbf{1}(\mathbf{b})$ at molar ratios $\mathbf{r}=$ [compound] $/$ [polynucleotide] $=0.4$ and 0.1 , respectively $(\mathrm{pH}=7.0$, buffer sodium cacodylate, $I=0.05 \mathrm{~mol} \mathrm{dm}{ }^{-3}+1 \mathrm{mM}$ EDTA).

Similar strong changes in CD spectra of polynucleotides were noticed with bis-polyaza pyridinophane derivatives that, similarly to compound 3, consist of two chains attached to pyridine as a central unit [66]. The reason that compound 3 induced condensation-like changes, while compound $\mathbf{1} \mathrm{did}$ not, is probably the position of chains on the pyridine ring. Unlike 1, 3 and bis-polyaza pyridinophane derivatives have two chains attached at the same positions on the pyridine ring ( 2 and 6 positions).

\subsubsection{Molecular Modeling}

The binding of 6 dimers inside the minor groove of the ATT triplex was also examined by molecular modeling (Figure 10). The mode of binding of $\mathbf{6}$ with the ATT triple structure suggested by the spectroscopic methods was consistent with the results obtained by molecular modeling.

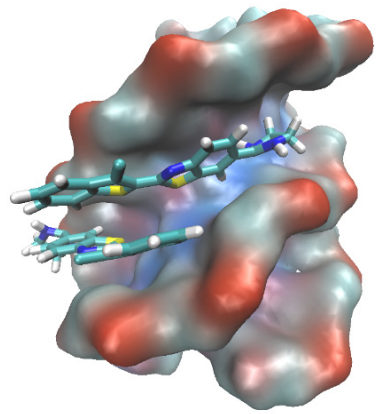

(a)

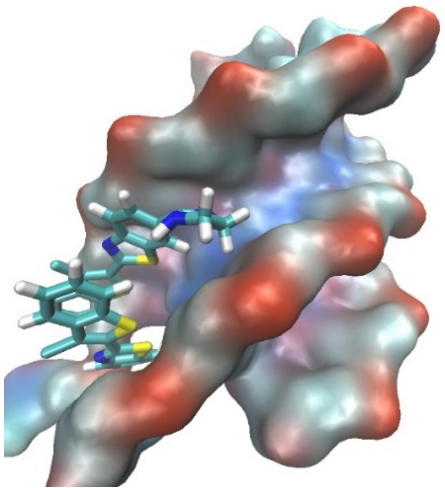

(b)

Figure 10. A complex between ATT (DNA triplex) and dimer of 6 obtained after 200 ns of MD simulation in water. ATT is represented by its solvent accessible surface and ligand is given in stick representation. (complexes were built in PyMOL, wherein the initial position of ligands was determined from spectroscopic data. Parametrization was performed by ANTECHAMBER [67] and Leap, the modules available within AMBER16 suite of programs [68,69] using GAFF [70] for the ligands and (a) bsc1 [41] and (b) OL15 [69] for ATT. Neutralized and solvated complexes were minimized, equilibrated, and simulated for $200 \mathrm{~ns}$ using the programs sander and pmemd. 


\section{Conclusions}

The search for small molecules with selective binding to specific sites in DNA or RNA structures is still of intense interest. Such binding can block or interfere with important processes, e.g., transcription, recombination, and DNA repair.

Competition dialysis assay $[27,71,72]$ allows the straightforward evaluation of sequence and structural selectivity of different DNA and RNA binding ligands. In this study it enabled the detection of three benzothiazole compounds, $(\mathbf{1}, \mathbf{5}$, and $\mathbf{6})$, with preferential binding to DNA:RNA hybrids and ATT triplex in regard to regular (non-hybrid) DNA and RNA duplexes and single-stranded forms.

Compound 6 preferentially stabilized dArU hybrid among other ds-polynucleotides. RNase $\mathrm{H}$ assay confirmed the results of thermal melting experiment (Table 3 ) and identified ligand 1 as a potential RNase $\mathrm{H}$ inhibitor for the digestion of poly rA-poly dT.

While all three compounds demonstrated a strong stabilization effect of ATT triplex, only compound 6, in both thermal melting experiments (Tables 3 and 4), demonstrated selective binding to ATT triplex in regard to AT duplex. Such stabilization could be exploited to inhibit the gene expression involved in cancer, for interference with DNA replication or inducing transcriptional repression, site-specific mutations, and recombination [11].

To the best of our knowledge, among small molecules previously reported [73-77], 6 with the chlorobenzothiophene substituent has the largest stabilization effect on ATT triplex $\left(\Delta T_{\mathrm{m}}=44\right.$ at $\left.\mathbf{r}=0.1\right)$. In addition, 5 (with bithiophene substituent) and, especially, 6 selective stabilization of triplex in the form of dimer inside the minor groove, has not been reported yet. The mode of binding of $\mathbf{6}$ (inside the ATT minor groove in the form of dimer) was confirmed by CD spectroscopy and molecular modeling. These results were made with long polynucleotides ( $\geq 500$ base pairs) that can provide a large excess of binding sites along the DNA helical structure and ease the determination of binding modes. To see if the same selectivity of molecule 6 toward ATT base triplets exists in shorter sequences, we performed measurements with the 26-nucleotide-long ATT triplex, possessing the same conformation (B-DNA, Figure 10) as its longer form. The fluorescence and CD experiments performed with 26 mer revealed high affinity and the same ICD profile as with longer sequences, confirming that the pattern of recognition is present regardless of nucleotide chain length.

As the AT-rich repeated sequences are often found in the sites for DNA replication initiation in bacterial, archaeal, and eukaryotic replicons, it would be interesting to confirm identified selectivity with a more distinct AT-rich oligomer sequence, for example, the GATCTATTTATTT of replication origin in E. coli [78]. However, this will be investigated in another study, after careful selection of the oligomers. Compound 6 could differentiate between B- and A-type helices by the mode of binding. While an appearance of negative ICD signals supported intercalation to A-type helices, poly dA-poly rU, and poly rA-poly $r U$, bisignate $C D$ signal implied the binding of 6 in the form of dimers inside the minor groove of poly $\mathrm{rA}$ - poly $\mathrm{dT}$, poly $\mathrm{dA}$ - poly $\mathrm{dT}$, and ATT triplex.

In contrast to its regioisomer 1, ligand 3 induced a strong increase in CD intensity of AT-rich sequences (ctDNA at $275 \mathrm{~nm}$, AT-DNA at 260 and $282 \mathrm{~nm}$, and ATT at $282 \mathrm{~nm}$ ) and strong positive ICD bands around $350 \mathrm{~nm}$ (Supplementary Materials). Similar condensationlike changes of the nucleic acid structure could be utilized in pharmaceutics for DNA delivery by viral or non-viral vectors in gene therapy [79-81]. Furthermore, DNA condensation can be applied in the construction of biosensors based on the liquid-crystalline properties of condensed DNA [82]. This result, as well as the identification of ligand 1 as a potential RNase $\mathrm{H}$ inhibitor, will be investigated in more detail and will be published elsewhere.

Supplementary Materials: The following supporting information can be downloaded at: https:/ / www.mdpi.com/article/10.3390/biom12030374/s1, Figure S1. UV/Vis spectra of 1-9 at c $=1.6 \times 10^{-5}$ to $2 \times 10^{-5} \mathrm{~mol} \mathrm{dm}^{-3} ; \mathrm{pH}=7$, sodium cacodylate/ $\mathrm{HCl}$ buffer, $\mathrm{I}=0.05 \mathrm{~mol} \mathrm{dm}^{-3}$, Figure S2. $\mathrm{UV} / \mathrm{Vis}$ spectra changes of $\mathbf{1}$ at different concentrations (concentration range from $5 \times 10^{-6}$ to $\left.2 \times 10^{-5} \mathrm{~mol} \mathrm{dm}^{-3}\right)(\mathbf{l e f t})$; linear dependence (-) of the absorbance at 223 and $330 \mathrm{~nm}(\mathbf{\square})$ on the 
1 concentration (right); $(\mathrm{pH}=7$, sodium cacodylate buffer, $I=0.05 \mathrm{M}$ ); Figure S3. UV/Vis spectra changes of 2 at different concentrations (concentration range from $5 \times 10^{-6}$ to $2 \times 10^{-5} \mathrm{~mol} \mathrm{dm}^{-3}$ ) (left); linear dependence (-) of the absorbance at 222 and $385 \mathrm{~nm}(\boldsymbol{\square})$ on the 2 concentration (right); ( $\mathrm{pH}=7$, sodium cacodylate buffer, $I=0.05 \mathrm{M}$ ); Figure S4. UV/Vis spectra changes of 3 at different concentrations (concentration range from $5 \times 10^{-6}$ to $2 \times 10^{-5} \mathrm{~mol} \mathrm{dm}^{-3}$ ) (left); linear dependence (-) of the absorbance at 223 and $330 \mathrm{~nm}(\boldsymbol{\square})$ on the 3 concentration (right); ( $\mathrm{pH}=7$, sodium cacodylate buffer, $I=0.05 \mathrm{M}$ ); Figure S5. UV/Vis spectra changes of 4 at different concentrations (concentration range from $5 \times 10^{-6}$ to $2 \times 10^{-5} \mathrm{~mol} \mathrm{dm}^{-3}$ ) (left); linear dependence (一) of the absorbance at 285 and $343 \mathrm{~nm}(\boldsymbol{\square})$ on the 4 concentration (right); ( $\mathrm{pH}=7$, sodium cacodylate buffer, $I=0.05 \mathrm{M}$ ); Figure S6. UV/Vis spectra changes of 5 at different concentrations (concentration range from $5 \times 10^{-6}$ to $\left.2 \times 10^{-5} \mathrm{~mol} \mathrm{dm}^{-3}\right)(\mathbf{l e f t})$; linear dependence (-) of the absorbance at $391 \mathrm{~nm}(\boldsymbol{\square})$ on the 5 concentration (right); $(\mathrm{pH}=7$, sodium cacodylate buffer, $I=0.05 \mathrm{M})$; Figure $\mathrm{S} 7$. UV/Vis spectra changes of 6 at different concentrations (concentration range from $5 \times 10^{-6}$ to $2 \times 10^{-5} \mathrm{~mol} \mathrm{dm}^{-3}$ ) (left); linear dependence $(-)$ of the absorbance at $342 \mathrm{~nm}(\boldsymbol{\square})$ on the 6 concentration (right); ( $\mathrm{pH}=7$, sodium cacodylate buffer, $I=0.05 \mathrm{M}$ ); Figure S8. UV/Vis spectra changes of 7 at different concentrations (concentration range from $5 \times 10^{-6}$ to $2 \times 10^{-5} \mathrm{~mol} \mathrm{dm}^{-3}$ ) (left); linear dependence (一) of the absorbance at 285 and $325 \mathrm{~nm}(\mathbf{\square})$ on the 7 concentration (right); $(\mathrm{pH}=7$, sodium cacodylate buffer, $I=0.05 \mathrm{M})$; Figure S9. UV/Vis spectra changes of 8 at different concentrations (concentration range from $5 \times 10^{-6}$ to $2 \times 10^{-5} \mathrm{~mol} \mathrm{dm}^{-3}$ ) (left); linear dependence (-) of the absorbance at $355 \mathrm{~nm}(\boldsymbol{\square})$ on the 8 concentration (right); $(\mathrm{pH}=7$, sodium cacodylate buffer, $I=0.05 \mathrm{M})$; Figure S10. UV/Vis spectra changes of 9 at different concentrations (concentration range from $5 \times 10^{-6}$ to $2 \times 10^{-5} \mathrm{~mol} \mathrm{dm}^{-3}$ ) (left); linear dependence (-) of the absorbance at 281 and $343 \mathrm{~nm}(\boldsymbol{\square})$ on the 9 concentration (right); $(\mathrm{pH}=7$, sodium cacodylate buffer, $I=0.05 \mathrm{M}$ ); Figure S11. Emission and excitation spectra changes of 1 at different concentrations at $\lambda_{\text {exc }}=330 \mathrm{~nm}$ (concentration range from $5 \times 10^{-7}$ to $2 \times 10^{-6} \mathrm{~mol} \mathrm{dm}^{-3}$ ) at $\mathrm{pH}=7.0$, sodium cacodylate buffer, $I=0.05 \mathrm{~mol} \mathrm{dm}^{-3}$; Figure S12. Emission and excitation spectra changes of 2 at different concentrations at $\lambda_{\mathrm{exc}}=285 \mathrm{~nm}$ (concentration range from $5 \times 10^{-7}$ to $2 \times 10^{-6} \mathrm{~mol} \mathrm{dm}^{-3}$ ) at $\mathrm{pH}=7.0$, sodium cacodylate buffer, $I=0.05 \mathrm{~mol} \mathrm{dm}^{-3}$; Figure S13. Emission and excitation spectra changes of 3 at different concentrations at $\lambda_{\mathrm{exc}}=330 \mathrm{~nm}$ (concentration range from $5 \times 10^{-7}$ to $2 \times 10^{-6} \mathrm{~mol} \mathrm{dm}{ }^{-3}$ ) at $\mathrm{pH}=7.0$, sodium cacodylate buffer, $I=0.05 \mathrm{~mol} \mathrm{dm}^{-3}$; Figure S14. Emission and excitation spectra changes of 4 at different concentrations at $\lambda_{\text {exc }}=343 \mathrm{~nm}$ (concentration range from $5 \times 10^{-7}$ to $2 \times 10^{-6} \mathrm{~mol} \mathrm{dm}^{-3}$ ) at $\mathrm{pH}=7.0$, sodium cacodylate buffer, $I=0.05 \mathrm{~mol} \mathrm{dm}^{-3}$; Figure S15. Emission and excitation spectra changes of 5 at different concentrations at $\lambda_{\text {exc }}=391 \mathrm{~nm}$ (concentration range from $5 \times 10^{-7}$ to $2 \times 10^{-6} \mathrm{~mol} \mathrm{dm}^{-3}$ ) at $\mathrm{pH}=7.0$, sodium cacodylate buffer, $I=0.05 \mathrm{~mol} \mathrm{dm}^{-3}$; Figure S16. Emission and excitation spectra changes of 6 at different concentrations at $\lambda_{\text {exc }}=342 \mathrm{~nm}$ (concentration range from $5 \times 10^{-7}$ to $2 \times 10^{-6} \mathrm{~mol} \mathrm{dm}^{-3}$ ) at $\mathrm{pH}=7.0$, sodium cacodylate buffer, $I=0.05 \mathrm{~mol} \mathrm{dm}^{-3}$; Figure S17. Emission and excitation spectra changes of 7 at different concentrations at $\lambda_{\text {exc }}=325 \mathrm{~nm}$ (concentration range from $5 \times 10^{-7}$ to 2 $\times 10^{-6} \mathrm{~mol} \mathrm{dm}^{-3}$ ) at $\mathrm{pH}=7.0$, sodium cacodylate buffer, $I=0.05 \mathrm{~mol} \mathrm{dm}^{-3}$; Figure S18. Emission and excitation spectra changes of 8 at different concentrations at $\lambda_{\mathrm{exc}}=355 \mathrm{~nm}$ (concentration range from $5 \times 10^{-7}$ to $2 \times 10^{-6} \mathrm{~mol} \mathrm{dm}^{-3}$ ) at $\mathrm{pH}=7.0$, sodium cacodylate buffer, $I=0.05 \mathrm{~mol} \mathrm{dm}^{-3}$; Figure S19. Emission and excitation spectra changes of 9 at different concentrations at $\lambda_{\text {exc }}=343$

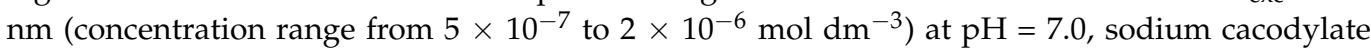
buffer, $I=0.05 \mathrm{~mol} \mathrm{dm}^{-3}$; Figure S20. Normalized emission spectra of benzothiazoles 1-9, $c=2 \times$ $10^{-6} \mathrm{~mol} \mathrm{dm}^{-3}$ at $\mathrm{pH}=7$, Na cacodylate buffer, $I=0.05 \mathrm{~mol} \mathrm{dm}^{-3}$; Figure S21. Left: Changes in fluorescence spectrum of $6\left(c=2 \times 10^{-7} \mathrm{~mol} \mathrm{dm}^{-3}, \lambda_{\mathrm{exc}}=342 \mathrm{~nm}\right)$ upon titration with poly dA - poly $\mathrm{rU}\left(c=9.9 \times 10^{-8}-7 \times 10^{-7} \mathrm{~mol} \mathrm{dm}^{-3}\right)$; Right: Experimental $(\bullet)$ and calculated (-) (by Scatchard eq.) fluorescence intensities of 6 at $\lambda_{\mathrm{em}}=429 \mathrm{~nm}$ upon addition of poly dA-poly $\mathrm{rU}(\mathrm{pH}=7.0$, Na cacodylate buffer, $I=0.2 \mathrm{~mol} \mathrm{dm}{ }^{-3}+1 \mathrm{mM}$ EDTA); Figure S22. Left: Changes in fluorescence spectrum of $6\left(c=2 \times 10^{-7} \mathrm{~mol} \mathrm{dm}^{-3}, \lambda_{\text {exc }}=342 \mathrm{~nm}\right)$ upon titration with ATT triplex $\left(c=9.9 \times 10^{-8}\right.$ $\left.-9.9 \times 10^{-7} \mathrm{~mol} \mathrm{dm}^{-3}\right)$; Right: Experimental $(\bullet)$ and calculated (-) (by Scatchard eq.) fluorescence intensities of 6 at $\lambda_{\mathrm{em}}=432 \mathrm{~nm}$ upon addition of ATT triplex $(\mathrm{pH}=7.0$, Na cacodylate buffer, $I=$ $0.05 \mathrm{~mol} \mathrm{dm}{ }^{-3}+1 \mathrm{mM}$ EDTA); Figure S23. Changes in fluorescence spectrum of $6\left(c=1 \times 10^{-6} \mathrm{~mol}\right.$ $\left.\mathrm{dm}^{-3}, \lambda_{\text {exc }}=342 \mathrm{~nm}\right)$ upon titration with 26mer ATT triplex $\left(c=5 \times 10^{-7}-6.36 \times 10^{-6} \mathrm{~mol} \mathrm{dm}^{-3}\right)$; Insert: Experimental $(\bullet)$ and calculated $(-)$ (by Scatchard eq.) fluorescence intensities of 6 at $\lambda_{\mathrm{em}}=$ $430 \mathrm{~nm}$ upon addition of $26 \mathrm{mer}$ ATT triplex $\left(\mathrm{pH}=7.0\right.$, Na cacodylate buffer, $I=0.05 \mathrm{~mol} \mathrm{dm}^{-3}+1$ mM EDTA); Figure S24. ITC experiment of ATT triplex titrated with 1; experimental data ( $\mathbf{\square})$ and calculated fit for model two sets of sites (-). Inset: raw titration data from the single injection of 1 
into a solution of ATT triplex; [ATT] $=3.0 \times 10^{-5} \mathrm{M} ; \mathrm{pH}=7.0$, Na-cacodylate buffer, $I=0.05 \mathrm{~mol}$ $\mathrm{dm}^{-3}+1$ mM EDTA; Figure S25. ITC experiment of poly rA-poly dT titrated with 1 ; experimental data ( $\square)$ and calculated fit for model two sets of sites (-). Inset: raw titration data from the single injection of 1 into a solution of poly $\mathrm{rA}$-poly dT hybrid; [ poly rA-poly dT] $=3.0 \times 10^{-5} \mathrm{M}$; $\mathrm{pH}$ $=7.0$, Na-cacodylate buffer, $I=0.05$ mol dm${ }^{-3}+1$ mM EDTA; Figure S26. Left: Melting curves of polynucleotide mixtures (50 mM sodium cacodylate buffer, $50 \mathrm{mM} \mathrm{NaCl}, 1 \mathrm{mM}$ EDTA): a DNA:RNA hybrid [poly dA-poly rU; peak 1], RNA [poly rA-poly rU; peak 2], an RNA:DNA hybrid [poly rA-poly dT; peak 3] and DNA [poly dA-poly dT; peak 4]. The concentration of each polynucleotide structure was $20 \mu \mathrm{M}(\mathrm{bp})$; total polynucleotide concentration is $80 \mu \mathrm{M}(\mathrm{bp})$. Effect of addition of ligand 1,5 , and $6(2 \mu \mathrm{M})$ at ratio, $\boldsymbol{r}([$ compound/[polynucleotide] $)=0.025$ to polynucleotide mixture was shown. Right: First derivative of absorbance at $260 \mathrm{~nm}$ in dependence of temperature; Figure S27. Left: Melting curve of ATT triplex upon addition of ratio, $\boldsymbol{r}$ ([compound/[polynucleotide]) $=0.1$ of 1 at $\mathrm{pH}=7.0$ (sodium cacodylate buffer with $\mathrm{NaCl}, I=0.1 \mathrm{~mol} \mathrm{dm}^{-3}+1 \mathrm{mM}$ EDTA); Right: First derivative of absorbance at $260 \mathrm{~nm}$ in dependence of temperature; Figure S28. Left: Melting curve of ATT triplex upon addition of ratio, $\boldsymbol{r}$ ([compound/[polynucleotide]) $=0.1$ of 5 at $\mathrm{pH}=7.0$ (sodium cacodylate buffer with $\mathrm{NaCl}, I=0.1 \mathrm{~mol} \mathrm{dm}^{-3}+1 \mathrm{mM}$ EDTA); Right: First derivative of absorbance at $260 \mathrm{~nm}$ in dependence of temperature; Figure S29. Left: Melting curve of ATT triplex upon addition of ratio, $r$ ([compound/[polynucleotide]) $=0.1$ of 6 at $\mathrm{pH}=7.0$ (sodium cacodylate buffer with $\mathrm{NaCl}, I=0.1 \mathrm{~mol} \mathrm{dm}{ }^{-3}+1 \mathrm{mM}$ EDTA); Right: First derivative of absorbance at 260 $\mathrm{nm}$ in dependence of temperature; Figure S30. Left: Melting curve of ATT triplex upon addition of ratio, $r$ ([compound/[polynucleotide]) $=0.1$ of 6 at $\mathrm{pH}=7.0$ (sodium cacodylate buffer with $\mathrm{NaCl}, I$ $=0.1 \mathrm{~mol} \mathrm{dm}{ }^{-3}+1 \mathrm{mM}$ EDTA); Right: First derivative of absorbance at $260 \mathrm{~nm}$ in dependence of temperature; Figure S31. CD titrations of ATT triplex, poly rA-poly dT, poly rA-poly rU and poly $\mathrm{dA}$ - poly rU $\left(c=3.0 \times 10^{-5} \mathrm{~mol} \mathrm{dm}^{-3}\right)$ with 6 at molar ratios $r=$ [compound] $/$ [polynucleotide] $=$ $0.3\left(\mathrm{pH}=7.0\right.$, buffer sodium cacodylate, $I=0.05 \mathrm{~mol} \mathrm{dm}{ }^{-3}+1 \mathrm{mM}$ EDTA for all titrations except poly dA-poly $\mathrm{rU}\left(I=0.2 \mathrm{~mol} \mathrm{dm}{ }^{-3}+1 \mathrm{mM}\right.$ EDTA $)$; Figure S32. CD titrations of ctDNA $(c=3.0$ $\left.\times 10^{-5} \mathrm{~mol} \mathrm{dm}{ }^{-3}\right)$ and poly rA-poly $\mathrm{rU}\left(c=3.0 \times 10^{-5} \mathrm{~mol} \mathrm{dm}^{-3}\right)$ with $\mathbf{1}, \mathbf{3}, \mathbf{5}$, and $\mathbf{6}$ at molar ratios $r=$ [compound]/[polynucleotide] ( $\mathrm{pH}=7.0$, buffer sodium cacodylate, $I=0.05 \mathrm{~mol} \mathrm{dm}^{-3}$ ); Figure S33. CD titrations of poly dA - poly rU $\left(c=3.0 \times 10^{-5} \mathrm{~mol} \mathrm{dm}^{-3}\right)$ and poly $\mathrm{rA}-$ poly dT $(c$ $\left.=3.0 \times 10^{-5} \mathrm{~mol} \mathrm{dm}^{-3}\right)$ with 1, 3, 5, and $\mathbf{6}$ at molar ratios $\boldsymbol{r}=$ [compound] $/$ [polynucleotide] $(\mathrm{pH}=$ 7.0, buffer sodium cacodylate, $I=0.05 \mathrm{~mol} \mathrm{dm}^{-3}$ ); Figure S34. CD titrations of poly dA - poly dT $\left(c=3.0 \times 10^{-5} \mathrm{~mol} \mathrm{dm}^{-3}\right)$ and ATT triplex $\left(c=3.0 \times 10^{-5} \mathrm{~mol} \mathrm{dm}^{-3}\right)$ with $\mathbf{1}, \mathbf{3}, \mathbf{5}$, and $\mathbf{6}$ at molar ratios $r=$ [compound]/[polynucleotide] ( $\mathrm{pH}=7.0$, buffer sodium cacodylate, $I=0.05 \mathrm{~mol} \mathrm{dm}^{-3}$ ); Figure S35. CD titration of ATT 26mer triplex $\left(c=3.0 \times 10^{-5} \mathrm{~mol} \mathrm{dm}^{-3}\right)$ and with 6 at molar ratios $r$ $=[$ compound $] /[$ polynucleotide $]\left(\mathrm{pH}=7.0\right.$, buffer sodium cacodylate, $\left.I=0.05 \mathrm{~mol} \mathrm{dm}^{-3}\right)$.

Author Contributions: Spectroscopic characterization of compounds in water and the study of interactions with nucleic acid structures, I.Z., L.-M.T. and M.R.S.; ITC titrations, I.C. and F.Š.; molecular modeling, S.T.; synthesis of benzothiazoles, L.R.; designing experiments, conceptualization, visualization, supervision, writing, and editing, L.-M.T., I.C. and M.R.S.; project administration and funding acquisition, M.R.S. All authors have read and agreed to the published version of the manuscript.

Funding: This research was funded by the Croatian Science Foundation project IP-2018-01-4694.

Institutional Review Board Statement: Not applicable.

Informed Consent Statement: Not applicable.

Data Availability Statement: Not applicable.

Acknowledgments: M.R.S. and I.Z. gratefully acknowledge the financial support from Croatian Science Foundation project IP-2018-01-4694.

Conflicts of Interest: The authors declare no conflict of interest.

\section{References}

1. Hurley, L.H. DNA and its associated processes as targets for cancer therapy. Nat. Cancer 2002, 2, 188-200. [CrossRef] [PubMed]

2. Demeunynck, M.; Bailly, C.; Wilson, W.D. Small Molecule DNA and RNA Binders: From Synthesis to Nucleic Acid Complexes; Demeunynck, M., Bailly, C., Wilson, W.D., Eds.; Wiley-VCH: Weinheim, Germany, 2003. 
3. Escudé, C.; Nguyen, C.H.; Kukreti, S.; Janin, Y.; Sun, J.-S.; Bisagni, E.; Garestier, T.; Hélène, C. Rational design of a triple helix-specific intercalating ligand. Proc. Natl. Acad. Sci. USA 1998, 95, 3591-3596. [CrossRef] [PubMed]

4. Arya, D.P. New Approaches Toward Recognition of Nucleic Acid Triple Helices. Acc. Chem. Res. 2011, 44, 134-146. [CrossRef] [PubMed]

5. Nguyen, T.Q.N.; Lim, K.W.; Phan, A.T. A Dual-Specific Targeting Approach Based on the Simultaneous Recognition of Duplex and Quadruplex Motifs. Sci. Rep. 2017, 7, 11969. [CrossRef]

6. Le, D.D.; Di Antonio, M.; Chan, L.K.M.; Balasubramanian, S. G-quadruplex ligands exhibit differential G-tetrad selectivity. Chem. Commun. 2015, 51, 8048-8050. [CrossRef]

7. Ranjan, N.; Davis, E.; Xue, L.; Arya, D.P. Dual recognition of the human telomeric G-quadruplex by a neomycin-anthraquinone conjugate. Chem. Commun. 2013, 49, 5796-5798. [CrossRef]

8. Van Dyke, M.W.; Ohyama, T. Do DNA Triple Helices or Quadruplexes Have a Role in Transcription? In DNA Conformation and Transcription; Springer Science and Business Media LLC: Berlin/Heidelberg, Germany, 2005; pp. 105-126.

9. Nadal, A.; Eritja, R.; Esteve, T.; Pla, M. "Parallel" and "antiparallel tail-clamps" increase the efficiency of triplex formation with structured DNA and RNA targets. ChemBioChem 2005, 6, 1034-1042. [CrossRef]

10. Wang, G.; Seidman, M.M.; Glazer, P.M. Mutagenesis in Mammalian Cells Induced by Triple Helix Formation and TranscriptionCoupled Repair. Science 1996, 271, 802-805. [CrossRef]

11. Jain, A.; Wang, G.; Vasquez, K.M. DNA triple helices: Biological consequences and therapeutic potential. Biochimie 2008, 90, 1117-1130. [CrossRef]

12. Xi, H.; Kumar, S.; Dosen-Micovic, L.; Arya, D.P. Calorimetric and spectroscopic studies of aminoglycoside binding to AT-rich DNA triple helices. Biochimie 2010, 92, 514-529. [CrossRef]

13. Sharma, S.K.; Frase, W. Selectivity of a bromoacridine containing fuorophore for triplex DNA. Mon. Chem. 2021, 152, 1013-1016. [CrossRef]

14. Xue, L.; Xi, H.; Kumar, S.; Gray, D.; Davis, E.; Hamilton, P.; Skriba, M.; Arya, D.P. Probing the Recognition Surface of a DNA Triplex: Binding Studies with Intercalator-Neomycin Conjugates. Biochemistry 2010, 49, 5540-5552. [CrossRef] [PubMed]

15. Mergny, J.L.; Duval-Valentin, G.; Nguyen, C.H.; Perrouault, L.; Faucon, B.; Rougée, M.; Montenay-Garestier, T.; Bisagni, E.; Hélène, C. Triple Helix-Specific Ligands. Science 1992, 256, 1681-1684. [CrossRef] [PubMed]

16. Houlard, M.; Artus, J.; Leguillier, T.; Vandormael-Pournin, S.; Cohen-Tannoudji, M. DNA-RNA hybrids contribute to the replication dependent genomic instability induced byOmcg1deficiency. Cell Cycle 2011, 10, 108-117. [CrossRef] [PubMed]

17. Balk, B.; Dees, M.; Bender, K.; Luke, B. The differential processing of telomeres in response to increased telomeric transcription and RNA-DNA hybrid accumulation. RNA Biol. 2014, 11, 95-100. [CrossRef] [PubMed]

18. Stuckey, R.; García-Rodríguez, N.; Aguilera, A.; Wellinger, R.E. Role for RNA:DNA hybrids in origin-independent replication priming in a eukaryotic system. Proc. Natl. Acad. Sci. USA 2015, 112, 5779-5784. [CrossRef]

19. Balk, B.; Maicher, A.; Dees, M.; Klermund, J.; Luke-Glaser, S.; Bender, K.; Luke, B. Telomeric RNA-DNA hybrids affect telomerelength dynamics and senescence. Nat. Struct. Mol. Biol. 2013, 20, 1199-1205. [CrossRef]

20. Li, T.-K.; Barbieri, C.M.; Lin, H.-C.; Rabson, A.B.; Yang, G.; Fan, Y.; Gaffney, B.L.; Jones, R.A.; Pilch, D.S. Drug Targeting of HIV-1 RNA.DNA Hybrid Structures: Thermodynamics of Recognition and Impact on Reverse Transcriptase-Mediated Ribonuclease H Activity and Viral Replication. Biochemistry 2004, 43, 9732-9742. [CrossRef]

21. Lombraña, R.; Almeida, R.; Alvarez, A.; Gómez, M. R-loops and initiation of DNA replication in human cells: A missing link? Front. Genet. 2015, 6, 158. [CrossRef]

22. Saretzki, G. Telomerase inhibition as cancer therapy. Cancer Lett. 2003, 194, 209-219. [CrossRef]

23. Mergny, J.-L.; Lacroix, L.; Teulade-Fichou, M.-P.; Hounsou, C.; Guittat, L.; Hoarau, M.; Arimondo, P.B.; Vigneron, J.-P.; Lehn, J.-M.; Riou, J.-F.; et al. Telomerase inhibitors based on quadruplex ligands selected by a fluorescence assay. Proc. Natl. Acad. Sci. USA 2001, 98, 3062-3067. [CrossRef] [PubMed]

24. Su, H.-P.; Yan, Y.; Prasad, G.S.; Smith, R.F.; Daniels, C.L.; Abeywickrema, P.D.; Reid, J.C.; Loughran, H.M.; Kornienko, M.; Sharma, S.; et al. Structural Basis for the Inhibition of RNase H Activity of HIV-1 Reverse Transcriptase by RNase H Active Site-Directed Inhibitors. J. Virol. 2010, 84, 7625-7633. [CrossRef] [PubMed]

25. Tramontano, E.; Di Santo, R. HIV-1 RT-associated RNase H function inhibitors: Recent advances in drug development. Curr. Med. Chem. 2010, 17, 2837-2853. [CrossRef]

26. Ren, J.; Qu, X.; Dattagupta, N.; Chaires, J. Molecular Recognition of a RNA:DNA Hybrid Structure. J. Am. Chem. Soc. 2001, 123, 6742-6743. [CrossRef]

27. Shaw, N.N.; Arya, D.P. Recognition of the unique structure of DNA:RNA hybrids. Biochimie 2008, 90, 1026-1039. [CrossRef] [PubMed]

28. West, C.; Francis, R.; Friedman, S.H. Small molecule/Nucleic acid affinity chromatography: Application for the identification of telomerase inhibitors which target its key RNA/DNA heteroduplex. Bioorganic Med. Chem. Lett. 2001, 11, 2727-2730. [CrossRef]

29. Wheelhouse, R.T.; Chaires, J.B. Drug binding to DNA x RNA hybrid structures. Methods Mol. Biol. 2010, 613, 55-70.

30. Shi, X.; Chaires, J.B. Sequence- and structural-selective nucleic acid binding revealed by the melting of mixtures. Nucleic Acids Res. 2006, 34, e14. [CrossRef]

31. Shaw, N.N.; Xi, H.; Arya, D.P. Molecular recognition of a DNA:RNA hybrid: Sub-nanomolar binding by a neomycin-methidium conjugate. Bioorganic Med. Chem. Lett. 2008, 18, 4142-4145. [CrossRef] 
32. Xi, H.; Davis, E.; Ranjan, N.; Xue, L.; Hyde-Volpe, D.; Arya, D.P. Thermodynamics of Nucleic Acid "Shape Readout" by an Aminosugar. Biochemistry 2011, 50, 9088-9113. [CrossRef]

33. Wheelhouse, R.T.; Garbett, N.C.; Buurma, N.J.; Chaires, J. Probing the Molecular Recognition of a DNA.RNA Hybrid Duplex Angew. Chem. Int. Ed. 2010, 49, 3207-3210. [CrossRef] [PubMed]

34. Racané, L.; Kraljević Pavelić, S.; Ratkaj, I.; Stepanić, V.; Pavelić, K.; Tralić-Kulenović, V.; Karminski-Zamola, G. Synthesis and antiproliferative evaluation of some new amidino-substituted bis-benzothiazolyl-pyridines and pyrazine. Eur. J. Med. Chem. 2012, 55, 108-116. [CrossRef] [PubMed]

35. Racané, L.; Sedić, M.; Ilić, N.; Aleksić, M.; Pavelić, S.K.; Karminski-Zamola, G. Novel 2-Thienyl- and 2-Benzothienyl-Substituted 6-(2-Imidazolinyl)Benzothiazoles: Synthesis; in vitro Evaluation of Antitumor Effects and Assessment of Mitochondrial Toxicity. Anti-Cancer Agents Med. Chem. 2017, 17, 57-66.

36. Racané, L.; Ptiček, L.; Sedić, M.; Grbčić, P.; Pavelić, S.K.; Bertosa, B.; Sović, I.; Karminski-Zamola, G. Eco-friendly synthesis, in vitro anti-proliferative evaluation, and 3D-QSAR analysis of a novel series of monocationic 2-aryl/heteroaryl-substituted 6-(2-imidazolinyl)benzothiazole mesylates. Mol. Divers. 2018, 22, 723-741. [CrossRef]

37. Chaires, J.; Dattagupta, N.; Crothers, D.M. Studies on interaction of anthracycline antibiotics and deoxyribonucleic acid: Equilibrium binding studies on the interaction of daunomycin with deoxyribonucleic acid. Biochemistry 1982, 21, 3933-3940. [CrossRef]

38. Chalikian, T.V.; Volker, J.; Plum, G.E.; Breslauer, K.J. A more unified picture for the thermodynamics of nucleic acid duplex melting: A characterization by calorimetric and volumetric techniques. Proc. Natl. Acad. Sci. USA 1999, 96, 7853-7858. [CrossRef]

39. Scatchard, G. The Attractions of Proteins for Small Molecules and Ions. Ann. N. Y. Acad. Sci. 1949, 51, 660-672. [CrossRef]

40. Ragazzon, P.; Chaires, J.B. Use of competition dialysis in the discovery of G-quadruplex selective ligands. Methods 2007, 43, 313-323. [CrossRef]

41. Ivani, I.; Dans, P.D.; Noy, A.; Pérez, A.; Faustino, I.; Hospital, A.; Walther, J.; Andrio, P.; Goñi, R.; Balaceanu, A.; et al. Parmbsc1: A Refined ForceField for DNA Simulations. Nat. Methods 2015, 13, 55-58. [CrossRef]

42. Schrödinger, L.; DeLano, W. The PyMOL Molecular Graphics System, Version 1.5.0.1.; Schrödinger, Inc.: New York, NY, USA, 2010

43. Jorgensen, W.L.; Chandrasekhar, J.; Madura, J.D.; Impey, R.W.; Klein, M.L. Comparison of simple potential functions for simulating liquid water. J. Chem. Phys. 1983, 79, 926-935. [CrossRef]

44. Li, P.; Roberts, B.P.; Chakravorty, D.K.; Merz, J.K.M. Rational Design of Particle Mesh Ewald Compatible Lennard-Jones Parameters for +2 Metal Cations in Explicit Solvent. J. Chem. Theory Comput. 2013, 9, 2733-2748. [CrossRef] [PubMed]

45. Loncharich, R.J.; Brooks, B.R.; Pastor, R.W. Langevin dynamics of peptides: The frictional dependence of isomerization rates ofN-acetylalanyl-N?-methylamide. Biopolymers 1992, 32, 523-535. [CrossRef] [PubMed]

46. Berendsen, H.J.C.; Postma, J.P.M.; Van Gunsteren, W.F.; DiNola, A.; Haak, J.R. Molecular dynamics with coupling to an external bath. J. Chem. Phys. 1984, 81, 3684. [CrossRef]

47. Košćak, M.; Krošl, I.; Žinić, B.; Piantanida, I. Fluorescent Analogues of FRH Peptide: Cu(II) Binding and Interactions with ds-DNA/RNA. Chemosensors 2022, 10, 34. [CrossRef]

48. Bronowska, A.K. Thermodynamics of Ligand-Protein Interactions: Implications for Molecular Design. In ThermodynamicsInteraction Studies—Solids, Liquids and Gases; IntechOpen: London, UK, 2011.

49. Perozzo, R.; Folkers, G.; Scapozza, L. Thermodynamics of Protein-Ligand Interactions: History, Presence, and Future Aspects. J. Recept. Signal Transduct. 2004, 24, 1-52. [CrossRef]

50. McGhee, J.D.; von Hippel, P.H. Theoretical aspects of DNA-protein interactions: Co-operative and non-co-operative binding of large ligands to a one-dimensional homogeneous lattice. J. Mol. Biol. 1974, 86, 469-489. [CrossRef]

51. Chaires, J.B. A thermodynamic signature for drug-DNA binding mode. Arch. Biochem. Biophys. 2006, 453, 26-31. [CrossRef]

52. Mergny, J.-L.; Lacroix, L. Analysis of Thermal Melting Curves. Oligonucleotides 2003, 13, 515-537. [CrossRef]

53. Lesnik, E.A.; Freier, S.M. Relative Thermodynamic Stability of DNA, RNA, and DNA:RNA Hybrid Duplexes: Relationship with Base Composition and Structure. Biochemistry 1995, 34, 10807-10815. [CrossRef]

54. Choi, B.-H.; Yeo, G.; Jung, J.; Lee, B.W.; Han, S.; Cho, T. A Thermodynamic Investigation into the Stabilization of Poly(dA)·[poly(dT)] 2 Triple Helical DNA by Various Divalent Metal Ions. Bull. Korean Chem. Soc. 2009, 30, $2691-2696$.

55. Arya, D.P.; Coffee, R.L.; Willis, B.; Abramovitch, A.I. Aminoglycoside-Nucleic Acid Interactions: Remarkable Stabilization of DNA and RNA Triple Helices by Neomycin. J. Am. Chem. Soc. 2001, 123, 5385-5395. [CrossRef] [PubMed]

56. Berova, N.; Nakanishi, K.; Woody, R. Circular Dichroism Principles and Applications, 2nd ed.; Wiley-VCH: New York, NY, USA, 2000.

57. Eriksson, M.; Nordén, B. Linear and circular dichroism of drug-nucleic acid complexes. In Methods in Enzymology; Elsevier BV: Amsterdam, The Netherlands, 2001; Volume 340, pp. 68-98.

58. Egli, M.; Saenger, W. Principles of Nucleic Acid Structure; Springer: Berlin/Heidelberg, Germany, 1983.

59. Cantor, C.R.; Schimmel, P.R. Biophysical Chemistry; W.H. Freeman: San Francisco, CA, USA, 1980.

60. Neidle, S. Oxford Handbook of Nucleic Acid Structure; Oxford University Press: Oxford, UK, 1999.

61. Fedoroff, O.Y.; Salazar, M.; Reid, B.R. Structure of a DNA: RNA Hybrid Duplex: Why RNase H Does Not Cleave Pure RNA. J. Mol. Biol. 1993, 233, 509-523. [CrossRef] [PubMed]

62. Radhakrishnan, I.; Patel, D.J. Solution structure of a pyrimidine-purine-pyrimidine DNA triplex containing T·AT, C+ GC and G.TA triples. Structure 1994, 2, 17-32. [CrossRef] 
63. Raghunathan, G.; Miles, H.T.; Sasisekharan, V. Symmetry and molecular structure of a DNA triple helix: D(T)n.cntdot.d(A)n.cntdot.d(T)n. Biochemistry 1993, 32, 455-462. [CrossRef]

64. Esguerra, M.; Nilsson, L.; Villa, A. Triple helical DNA in a duplex context and base pair opening. Nucleic Acids Res. 2014, 42, 11329-11338. [CrossRef]

65. Šmidlehner, T.; Piantanida, I.; Pescitelli, G. Polarization spectroscopy methods in the determination of interactions of small molecules with nucleic acids-Tutorial. Beilstein J. Org. Chem. 2018, 14, 84-105. [CrossRef]

66. Stojković, M.R.; González-García, J.; Šupljika, F.; Galiana-Roselló, C.; Guijarro, L.; Gazzè, S.A.; Francis, L.W.; Piantanida, I.; García-España, E. Specific and highly efficient condensation of GC and IC DNA by polyaza pyridinophane derivatives. Int. J. Biol. Macromol. 2017, 109, 143-151. [CrossRef]

67. Wang, J.; Wang, W.; Kollman, P.A.; Case, D.A. Automatic atom type and bond type perception in molecular mechanical calculations. J. Mol. Graph. Model. 2006, 25, 247-260. [CrossRef]

68. Case, D.; Betz, R.; Cerutti, D.S.; Cheatham, T.; Darden, T.; Duke, R.; Giese, T.J.; Gohlke, H.; Götz, A.; Homeyer, N.; et al. Amber 16; University of California: San Francisco, CA, USA, 2016.

69. Zgarbová, M.; Šponer, J.; Otyepka, M.; Cheatham, I.T.E.; Galindo-Murillo, R.; Jurečka, P. Refinement of the Sugar-Phosphate Backbone Torsion Beta for AMBER Force Fields Improves the Description of Z- and B-DNA. J. Chem. Theory Comput. 2015, 11, 5723-5736. [CrossRef]

70. Wang, J.; Wolf, R.M.; Caldwell, J.W.; Kollman, P.A.; Case, D.A. Development and testing of a general amber force field. J. Comput. Chem. 2004, 25, 1157-1174. [CrossRef]

71. Gmeiner, W.H.; Cui, W.; Sharma, S.; Soto, A.M.; Marky, L.A.; Lown, J.W. Shape-Selective Binding of Geometrically-Constrained bis-Distamycins to a DNA Duplex and a Model Okazaki Fragment of Identical Sequence. Nucleosides Nucleotides Nucleic Acids 2000, 19, 1365-1379. [CrossRef] [PubMed]

72. Ren, J.; Chaires, J.B. Sequence and Structural Selectivity of Nucleic Acid Binding Ligands. Biochemistry 1999, 38, 16067-16075. [CrossRef] [PubMed]

73. Yamayoshi, A.; Miyoshi, D.; Zouzumi, Y.-K.; Matsuyama, Y.; Ariyoshi, J.; Shimada, N.; Murakami, A.; Wada, T.; Maruyama, A. Selective and Robust Stabilization of Triplex DNA Structures Using Cationic Comb-type Copolymers. J. Phys. Chem. B 2017, 121, 4015-4022. [CrossRef] [PubMed]

74. Kan, Y.; Armitage, B.; Schuster, G.B. Selective Stabilization of Triplex DNA by Anthraquinone Sulfonamide Derivatives. Biochemistry 1997, 36, 1461-1466. [CrossRef]

75. Ren, J.; Chaires, J.B. Preferential Binding of 3,3'-Diethyloxadicarbocyanine to Triplex DNA. J. Am. Chem. Soc. 1999, 122, $424-425$. [CrossRef]

76. Tam, V.K.; Liu, Q.; Tor, Y. Extended ethidium bromide analogue as a triple helix intercalator: Synthesis, photophysical properties and nucleic acids binding. Chem. Commun. 2006, 25, 2684-2686. [CrossRef]

77. Latimer, L.J.P.; Payton, N.; Forsyth, G.; Lee, J.S. The binding of analogues of coralyne and related heterocyclics to DNA triplexes. Biochem. Cell Biol. 1995, 73, 11-18. [CrossRef]

78. Rajewska, M.; Wegrzyn, K.; Konieczny, I. AT-rich region and repeated sequences-The essential elements of replication origins of bacterial replicons. FEMS Microbiol. Rev. 2012, 36, 408-434. [CrossRef]

79. Vijayanathan, V.; Thomas, T. DNA Nanoparticles and Development of DNA Delivery Vehicles for Gene Therapy. Biochemistry 2002, 41, 14085-14094. [CrossRef]

80. Kotterman, M.A.; Schaffer, D.V. Engineering adeno-associated viruses for clinical gene therapy. Nat. Rev. Genet. 2014, 15, 445-451 [CrossRef]

81. Lee, A.; Karcz, A.P.; Akman, R.; Zheng, T.; Kwon, S.; Chou, S.-T.; Sucayan, S.; Tricoli, L.J.; Hustedt, J.M.; Leng, Q.; et al. Direct observation of dynamic mechanical regulation of DNA condensation by environmental stimuli. Angew. Chem. Int. Ed. 2014, 53, 10631-10635. [CrossRef] [PubMed]

82. Yevdokimov, Y.M. Double-stranded DNA liquid-crystalline dispersions as biosensing units. Biochem. Soc. Trans. 2000, 28, 77-81. [CrossRef] [PubMed] 